\title{
Cloud condensation nuclei in polluted air and biomass burning smoke near the mega-city Guangzhou, China - Part 2: Size-resolved aerosol chemical composition, diurnal cycles, and externally mixed weakly $\mathrm{CCN}$-active soot particles
}

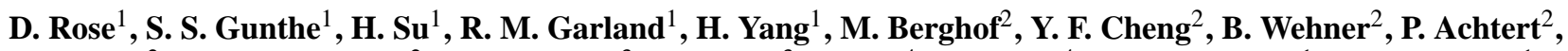 \\ A. Nowak ${ }^{2}$, A. Wiedensohler ${ }^{2}$, N. Takegawa ${ }^{3}$, Y. Kondo ${ }^{3}$, M. Hu ${ }^{4}$, Y. Zhang ${ }^{4}$, M. O. Andreae ${ }^{1}$, and U. Pöschl ${ }^{1}$ \\ ${ }^{1}$ Biogeochemistry Department, Max Planck Institute for Chemistry, Mainz, Germany \\ ${ }^{2}$ Leibniz Institute for Tropospheric Research, Leipzig, Germany \\ ${ }^{3}$ RCAST, University of Tokyo, Tokyo, Japan \\ ${ }^{4}$ State Key Joint Laboratory of Environmental Simulation and Pollution Control, College of Environmental Sciences and \\ Engineering, Peking University, Beijing, China
}

Received: 29 October 2010 - Published in Atmos. Chem. Phys. Discuss.: 9 November 2010

Revised: 4 March 2011 - Accepted: 8 March 2011 - Published: 25 March 2011

\begin{abstract}
Size-resolved chemical composition, mixing state, and cloud condensation nucleus (CCN) activity of aerosol particles in polluted mega-city air and biomass burning smoke were measured during the PRIDE-PRD2006 campaign near Guangzhou, China, using an aerosol mass spectrometer (AMS), a volatility tandem differential mobility analyzer (VTDMA), and a continuous-flow CCN counter (DMT-CCNC).

The size-dependence and temporal variations of the effective average hygroscopicity parameter for $\mathrm{CCN}$-active particles $\left(\kappa_{\mathrm{a}}\right)$ could be parameterized as a function of organic and inorganic mass fractions $\left(f_{\text {org }}, f_{\text {inorg }}\right)$ determined by the AMS: $\kappa_{\mathrm{a}, \mathrm{p}}=\kappa_{\text {org }} \cdot f_{\text {org }}+\kappa_{\text {inorg }} \cdot f_{\text {inorg }}$. The characteristic $\kappa$ values of organic and inorganic components were similar to those observed in other continental regions of the world: $\kappa_{\text {org }} \approx 0.1$ and $\kappa_{\text {inorg }} \approx 0.6$. The campaign average $\kappa_{\mathrm{a}}$ values increased with particle size from $\sim 0.25$ at $\sim 50 \mathrm{~nm}$ to $\sim 0.4$ at $\sim 200 \mathrm{~nm}$, while $f_{\text {org }}$ decreased with particle size. At $\sim 50 \mathrm{~nm}, f_{\text {org }}$ was on average $60 \%$ and increased to almost $100 \%$ during a biomass burning event.

The VTDMA results and complementary aerosol optical data suggest that the large fractions of $\mathrm{CCN}$-inactive particles observed at low supersaturations (up to $60 \%$ at $S \leq 0.27 \%$ ) were externally mixed weakly $\mathrm{CCN}$-active soot particles with low volatility (diameter reduction $<5 \%$ at $300^{\circ} \mathrm{C}$ ) and
\end{abstract}

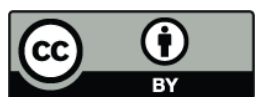

Correspondence to: D. Rose (d.rose@mpic.de) effective hygroscopicity parameters around $\kappa_{\mathrm{LV}} \approx 0.01$. A proxy for the effective average hygroscopicity of the total ensemble of $\mathrm{CCN}$-active particles including weakly $\mathrm{CCN}$ active particles $\left(\kappa_{\mathrm{t}}\right)$ could be parameterized as a function of $\kappa_{\mathrm{a}, \mathrm{p}}$ and the number fraction of low volatility particles determined by VTDMA $\left(\phi_{\mathrm{LV}}\right): \kappa_{\mathrm{t}, \mathrm{p}}=\kappa_{\mathrm{a}, \mathrm{p}}-\phi_{\mathrm{LV}} \cdot\left(\kappa_{\mathrm{a}, \mathrm{p}}-\kappa_{\mathrm{LV}}\right)$.

Based on $\kappa$ values derived from AMS and VTDMA data, the observed $\mathrm{CCN}$ number concentrations $\left(N_{\mathrm{CCN}, \mathrm{S}} \approx 10^{2}-\right.$ $10^{4} \mathrm{~cm}^{-3}$ at $S=0.068-0.47 \%$ ) could be efficiently predicted from the measured particle number size distribution. The mean relative deviations between observed and predicted $\mathrm{CCN}$ concentrations were $\sim 10 \%$ when using $\kappa_{\mathrm{t}, \mathrm{p}}$, and they increased to $\sim 20 \%$ when using only $\kappa_{\mathrm{a}, \mathrm{p}}$. The mean relative deviations were not higher $(\sim 20 \%)$ when using an approximate continental average value of $\kappa \approx 0.3$, although the constant $\kappa$ value cannot account for the observed temporal variations in particle composition and mixing state (diurnal cycles and biomass burning events).

Overall, the results confirm that on a global and climate modeling scale an average value of $\kappa \approx 0.3$ can be used for approximate predictions of $\mathrm{CCN}$ number concentrations in continental boundary layer air when aerosol size distribution data are available without information about chemical composition. Bulk or size-resolved data on aerosol chemical composition enable improved $\mathrm{CCN}$ predictions resolving regional and temporal variations, but the composition data need to be highly accurate and complemented by information about particle mixing state to achieve high precision (relative deviations $<20 \%$ ).

Published by Copernicus Publications on behalf of the European Geosciences Union. 


\section{Introduction}

Atmospheric aerosol particles serving as cloud condensation nuclei $(\mathrm{CCN})$ play an important role in the formation of clouds and precipitation, and influence atmospheric chemistry and physics, the hydrological cycle and climate (Pruppacher and Klett, 1997; Seinfeld and Pandis, 2006; Lohmann and Feichter, 2005; IPCC, 2007; Heintzenberg and Charlson, 2009).

Substantial progress has been made in recent years in understanding the source processes that produce cloud-active aerosols, the properties that enable aerosols to act as $\mathrm{CCN}$, the effects of aerosols on cloud physics and precipitation, and the consequences for the climate system (Andreae and Rosenfeld, 2008; Stevens and Feingold, 2009; Pöschl et al., 2009, and references therein). To incorporate the effects of $\mathrm{CCN}$ in meteorological models at all scales, from large eddy simulation (LES) to global climate models (GCM), knowledge of the spatial and temporal distribution of $\mathrm{CCN}$ in the atmosphere is essential (Huang et al., 2007). Several studies reported $\mathrm{CCN}$ measurements from various regions around the world (e.g., Andreae, 2009; Andreae and Rosenfeld, 2008; Bougiatioti et al., 2009; Broekhuizen et al., 2006; Chang et al., 2010; Dusek et al., 2006, 2010; Ervens et al., 2010; Gunthe et al., 2009; Hudson and Yum, 2002; Lance et al., 2009; Roberts et al., 2001, 2002, 2006; Shantz et al., 2010; Wang et al., 2008, 2010; Yum and Hudson, 2004; Yum et al., 2005). However, the actual influence and relative importance of aerosol size distribution, chemical composition, and mixing state on the variability and predictability of CCN concentrations remained a subject of continued discussion (e.g., Broekhuizen et al., 2006; Dusek et al., 2006; Hudson, 2007; Cubison et al., 2008; Kuwata et al., 2008; Wang et al., 2008; Bougiatioti et al., 2009; Gunthe et al., 2009; Ervens et al., 2010; Jurányi et al., 2010; Rose et al., 2010a; Wex et al., 2010). Size-resolved measurements, long-term data sets, and uncertainty analyses of $\mathrm{CCN}$ modeling techniques are needed to resolve these issues.

Part 1 of this study (Rose et al., 2010a) presented the CCN properties of aerosol particles in polluted air and biomass smoke near the mega-city Guangzhou, China, as measured within the "Program of Regional Integrated Experiments of Air Quality over the Pearl River Delta" intensive campaign in July 2006 (PRIDE-PRD2006). Different model approaches for the prediction of the CCN number concentrations were tested. With a $\kappa$-Köhler model (Petters and Kreidenweis, 2007) using the measured particle hygroscopicity and number size distribution, the error in the prediction was on average less than $\sim 10 \%$. Using a constant average hygroscopicity parameter $(\kappa=0.3)$ and variable size distributions as measured, the deviations between observed and predicted CCN concentrations were on average still less than $20 \%$. These and other sensitivity tests in related studies (e.g., Dusek et al., 2006; Gunthe et al., 2009; Jurányi et al., 2010) suggest that the variability in particle number and size are more impor- tant than that in chemical composition and hygroscopicity for predicting the variability of $\mathrm{CCN}$ concentrations in continental boundary layer air. The mixing state of the particles with regard to their hygroscopicity, however, seems to be important for accurate CCN predictions (Medina et al., 2007; Cubison et al., 2008; Anttila, 2010; Ervens et al., 2010; Su et al., 2010; Wang et al., 2010). Especially since close to anthropogenic sources aerosols typically comprise externally mixed carbonaceous particles (soot) with distinctive hygroscopic properties (Cubison et al., 2008; Kuwata et al., 2007; Kuwata and Kondo, 2008; Wang et al., 2010).

In this manuscript, we use the same $\mathrm{CCN}$ data set from the Chinese mega-city Guangzhou as presented in Rose et al. (2010a) to investigate whether including detailed information about aerosol chemical composition and mixing state from complementary measurements improve the predictability of CCN concentrations. For this purpose we apply data from aerosol mass spectrometry (AMS) and volatility tandem differential mobility analyzer (VTDMA) measurements that were performed in parallel to the $\mathrm{CCN}$ measurements during PRIDE-PRD2006.

In Sect. 3.1, we show how AMS data can be used for efficient prediction of the average effective hygroscopicity of $\mathrm{CCN}$-active particles, assuming internal mixing of inorganic and organic components (e.g., Ervens et al., 2010; Cubison et al., 2008; Gunthe et al., 2009). In Sect. 3.2, we derive an approximate average $\kappa$ value for externally mixed, weakly $\mathrm{CCN}$-active soot particles, and we address their influence on the prediction of CCN concentrations. In Sect. 3.3, we present diurnal cycles of CCN, AMS, VTDMA, and complementary aerosol optical parameters, and we discuss how they are linked to local and regional aerosol sources.

\section{Methods}

\subsection{Measurement location}

The measurements were performed during the period of 1-30 July 2006 in Backgarden $\left(23.55^{\circ} \mathrm{N}, 113.07^{\circ} \mathrm{E}\right)$, a small village $\sim 60 \mathrm{~km}$ northwest of Guangzhou on the outskirts of the densely populated center of the Pearl River Delta (PRD). Due to the prevailing monsoon circulation at this time of year, the air masses came mainly from the south/southeast, making this site a rural receptor site for the regional pollution resulting from the outflow of the city cluster around Guangzhou. For more information about the measurement location and meteorological conditions see Garland et al. (2008) and Rose et al. (2010a). 
Table 1. List and short description of CCN parameters and other symbols used in this study. The first four variables are fit parameters of a cumulative Gaussian distribution function (CDF) fit of the CCN efficiency spectrum (Eq. (1) of Rose et al., 2010a). The $\kappa$ parameters are effective hygroscopicity parameters (Petters and Kreidenweis, 2007). Details about the definition and determination of all parameters can be found in Rose et al. (2010a).

\begin{tabular}{|c|c|c|}
\hline Symbol & Unit & Description \\
\hline$D_{\mathrm{a}}$ & $\mathrm{nm}$ & midpoint activation diameter determined by a 3-parameter CDF fit \\
\hline$\sigma_{\mathrm{a}}$ & $\mathrm{nm}$ & $\begin{array}{l}\text { standard deviation of a 3-parameter } \mathrm{CDF} \text { fit; characterizes the } \\
\text { heterogeneity of CCN-active particles in the size range around } D_{\mathrm{a}}\end{array}$ \\
\hline$D_{\mathrm{t}}$ & $\mathrm{nm}$ & $\begin{array}{l}\text { midpoint activation diameter determined by a 2-parameter CDF fit } \\
\text { in which the maximum is limited to unity }\end{array}$ \\
\hline $\mathrm{MAF}_{\mathrm{f}}$ & & maximum activated fraction determined by a 3-parameter CDF fit \\
\hline $\mathrm{MAF}_{\mathrm{m}}$ & & activated fraction measured at the largest selected diameter $(\sim 270 \mathrm{~nm})$ \\
\hline$\kappa_{\mathrm{a}}$ & & $\begin{array}{l}\text { hygroscopicity parameter characteristic for internally mixed } \\
\text { CCN-active particles; calculated from the fit parameter } D_{\mathrm{a}}\end{array}$ \\
\hline$\kappa_{\mathrm{t}}$ & & $\begin{array}{l}\text { hygroscopicity parameter characteristic for the total ensemble of } \\
\text { aerosol particles, including internally mixed CCN-active particles } \\
\text { as well as externally mixed weakly CCN-active particles; derived } \\
\text { from the fit parameter } D_{\mathrm{t}}\end{array}$ \\
\hline$\kappa_{\mathrm{a}, \mathrm{p}}$ & & $\begin{array}{l}\text { predicted } \kappa \text { value as calculated from Eq. (1); characteristic for } \\
\text { internally mixed CCN-active particles }\end{array}$ \\
\hline$\kappa_{\mathrm{t}, \mathrm{p}}$ & & $\begin{array}{l}\text { predicted } \kappa \text { value as calculated from Eqs. (3), (4), or (5); proxy for } \\
\text { total ensemble of aerosol particles }\end{array}$ \\
\hline$\kappa_{\mathrm{LV}}$ & & effective hygroscopicity of particles with low volatility \\
\hline$N_{\mathrm{CCN}, \mathrm{S}}$ & $\mathrm{cm}^{-3}$ & number concentration of $\mathrm{CCN}$ at supersaturation $S$ \\
\hline$N_{\mathrm{CCN}, \mathrm{S}, \mathrm{p}}$ & $\mathrm{cm}^{-3}$ & predicted number concentration of $\mathrm{CCN}$ at supersaturation $S$ \\
\hline$D$ & $\mathrm{~nm}$ & mobility equivalent particle diameter \\
\hline$D_{\mathrm{VT}}$ & $\mathrm{nm}$ & particle diameter selected by the VTDMA \\
\hline$f_{\text {inorg }}$ & & $\begin{array}{l}\text { inorganic mass fraction detected by the AMS } \\
\text { organic mass fraction detected by the AMS }\end{array}$ \\
\hline$m_{\mathrm{D}}$ & $\mu \mathrm{g} \mathrm{m}^{-3}$ & $\begin{array}{l}\text { AMS mass concentrations integrated over the size interval } \\
\text { of } D_{\mathrm{a}}-\sigma_{\mathrm{a}} \text { to } D_{\mathrm{a}}+\sigma_{\mathrm{a}}\end{array}$ \\
\hline$S$ & $\%$ & water vapor supersaturation \\
\hline$S_{\mathrm{c}}$ & $\%$ & critical supersaturation \\
\hline$\kappa_{\text {inorg }}$ & & effective hygroscopicity of the inorganic mass \\
\hline$\kappa_{\mathrm{org}}$ & & effective hygroscopicity of the organic mass \\
\hline$\phi_{\mathrm{LV}}$ & & number fraction of low volatility (LV-) particles \\
\hline $\begin{array}{l}\phi_{\mathrm{LV}, \mathrm{D}_{\mathrm{a}}} \\
\omega_{532}\end{array}$ & & $\begin{array}{l}\text { number fraction of LV-particles at } D_{\mathrm{VT}} \text { that is closest to } D_{\mathrm{a}} \\
\text { single scattering albedo at } 532 \mathrm{~nm} \text { wavelength }\end{array}$ \\
\hline
\end{tabular}

\subsection{Instrumentation and data processing}

\subsubsection{Aerosol inlet system}

The main aerosol inlet used in this study was equipped with a Rupprecht and Patashnick $\mathrm{PM}_{10}$ inlet (flow rate 16.7 $\mathrm{L} \mathrm{min}^{-1}$ ). The sample flow passed through stainless steel tubing (1.9 cm inner diameter (i.d.), $5.1 \mathrm{~m}$ length) and a diffusion dryer with silica gel/molecular sieve cartridges (alternating regeneration with dry pressurized air, regeneration cycles $15-50 \mathrm{~min}$, average $\mathrm{RH}=33 \pm 7 \%$ ). After drying in this automated aerosol dryer (Tuch et al., 2009), the sample flow was split into separate lines. One led to the CCN measurement setup described below $(0.9 \mathrm{~cm}$ i.d. stainless steel, $\sim 4 \mathrm{~m}$ length, flow rate $1.5 \mathrm{~L} \mathrm{~min}^{-1}$ ), one to the setup measuring aerosol optical properties, and another one was used for aerosol particle size distribution measurements (3-900 nm) with a twin differential mobility particle sizer (TDMPS), and volatility measurements with a volatility tandem differential mobility analyzer (VTDMA). The inlet, dryer, size distribution measurements, and volatility measurements were operated by the Leibniz Institute for Tropospheric Research (IfT).
The aerosol mass spectrometry (AMS) data employed in this study were acquired by the University of Tokyo using a separate aerosol inlet system. The sample air for the AMS was aspirated from the rooftop of the building using a stainless steel tube of $\sim 6 \mathrm{~m}$ with an inner diameter of $10 \mathrm{~mm}$. A $\mathrm{PM}_{2.5}$ cyclone (flow rate $10 \mathrm{~L} \mathrm{~min}^{-1}$; URG Corp., USA) was used for the inlet to remove coarse particles, although the actual size-cut of the AMS is determined by the more restrictive transmission characteristics of its aerodynamic lens (approximately $\mathrm{PM}_{1}$ ). The $10 \mathrm{~mm}$ tube was reduced to a tube with an i.d. of $4.4 \mathrm{~mm}$ and subsequently to a tube with an i.d. of $2.0 \mathrm{~mm}(\sim 0.49 \mathrm{~m}$ length) using two isokinetic manifolds in order to match the AMS sample flow and orifice assembly. The temperature of the tube and the AMS orifice was controlled at a constant value $\left(40^{\circ} \mathrm{C}\right.$ or $42^{\circ} \mathrm{C}$, depending on ambient dew point) to dry the particles in the sample air. The relative humidity in the sample air was calculated to be within the range of $30-45 \%$ for the entire period of the campaign.

\subsubsection{Cloud condensation nuclei $(\mathrm{CCN})$}

Size-resolved CCN efficiency spectra (CCN activation curves, $16 \mathrm{~min}$ time resolution) were measured with a Droplet Measurement Technologies continuous-flow CCN counter (DMT-CCNC; Roberts and Nenes, 2005; Lance et al., 2006) coupled to a differential mobility analyzer (DMA; TSI 3071) and a condensation particle counter (CPC; TSI 3762; Frank et al., 2006; Rose et al., 2008). The sheath air flow of the DMA was dried with a silica gel diffusion dryer to an average $\mathrm{RH}$ of $<5 \%$. In this setup the particles are rapidly dried upon entering the DMA. Thus, size selection is effectively performed under dry conditions, and the relative deviations in particle diameter should be $<1 \%$ except for potential kinetic limitations (Mikhailov et al., 2009). Key parameters derived from the measured $\mathrm{CCN}$ efficiency spectra are briefly explained and listed in Table 1. For a detailed description of the parameters and more details about the measurement procedure, calibration, and data analysis see Part 1 of this study (Rose et al., 2010a).

During PRIDE-PRD 2006, CCN data were recorded for six supersaturation $(S)$ levels between $0.068 \%$ and $1.27 \%$, but two levels ( $S=0.67 \%$ and $S=1.27 \%$ ) were not measured throughout the entire campaign (see Fig. 5 a, b of Rose et al., 2010a). To avoid potential biases due to different averaging times, the data points measured at these $S$ were omitted in the correlation analyses of this paper.

CCN size distributions were calculated by multiplying the $\mathrm{CCN}$ efficiency spectra (3-parameter CDF fit, Table 1) with the total aerosol particle $(\mathrm{CN})$ number size distribution measured in parallel by a TDMPS (Sect. 2.2.6). Total CCN number concentrations $\left(N_{\mathrm{CCN}, \mathrm{S}}\right)$ were obtained by integration of the $\mathrm{CCN}$ size distributions. 


\subsubsection{Aerosol mass spectrometry (AMS)}

An Aerodyne quadrupole aerosol mass spectrometer (QAMS, referred to as "AMS" for brevity) was used to measure the size-resolved chemical composition of non-refractory $\left(\sim 600^{\circ} \mathrm{C}\right)$ submicron aerosol particles (Jayne et al., 2000). The performance of the AMS during the PRIDE-PRD2006 campaign is described in detail by Takegawa et al. (2009). The AMS data used in this study comprise a time series of mass size distributions ( $\mathrm{d} M / \mathrm{d} \log D_{\mathrm{va}}, \sim 10$ min time resolution) where $D_{\mathrm{va}}$ is the vacuum aerodynamic diameter (DeCarlo et al., 2004). The mass size distributions were calculated for inorganic ions $\left(\mathrm{SO}_{4}^{2-}, \mathrm{NH}_{4}^{+}, \mathrm{NO}_{3}^{-}, \mathrm{Cl}^{-}\right)$and organic matter (Org) in the size range between $45 \mathrm{~nm}$ and $1.4 \mu \mathrm{m}$.

The mass concentration data of each size bin were averaged with the two adjacent size bins to minimize the influence of noise. To make the size-resolved AMS results directly comparable with the CCN and VTDMA measurement results, all calculations and plots in this study using AMS data were based on approximate mobility equivalent diameters that have been calculated by division of the AMS vacuum aerodynamic diameter by a scaling factor of 1.7 , which is based on the assumption of an effective particle density of $1.7 \mathrm{~g} \mathrm{~cm}^{-3}$ as reported for similar locations (Cheng et al., 2006; Zhang et al., 2009). Accordingly, the scaled AMS mass size distributions span a mobility diameter range of $27 \mathrm{~nm}$ to $850 \mathrm{~nm}$ and in the remainder of this study we refer only to mobility equivalent diameters.

For further analysis, only the mass concentrations measured at particle sizes $>50 \mathrm{~nm}$ were used. Below this size, the reliability of the AMS data was low due to the low detection efficiency of the instrument. Size-resolved mass fractions were calculated diameter-wise from the size distributions of mass concentration. The mass fraction of one chemical component is its mass concentration divided by the sum of the masses of all AMS measured components at this diameter.

To describe the chemical composition of the particles activated at the midpoint of the CCN efficiency spectrum, the AMS mass concentrations were integrated over the size interval of $D_{\mathrm{a}}-\sigma_{\mathrm{a}}$ to $D_{\mathrm{a}}+\sigma_{\mathrm{a}}$ (activation diameter $\pm \mathrm{CDF}$ standard deviation). The mass concentrations within these intervals $\left(m_{\mathrm{D}}\right)$ were used to calculate mass fractions of inorganic and organic components ( $f_{\text {inorg }}, f_{\text {org }}$ ) for further analysis (e.g., correlation analysis). $\mathrm{CCN}$ efficiency spectra with $D_{\mathrm{a}}-\sigma_{\mathrm{a}}<50 \mathrm{~nm}$ were excluded from further analysis. Thus, all CCN efficiency spectra measured at $S=0.87 \%$ and a part of those at $S=0.47 \%$ were excluded in the correlation analysis between $\mathrm{CCN}$ and AMS data.

Note that for a density correction factor lower than 1.7, the mobility equivalent diameter range for the AMS data would be linearly shifted to larger values. The effects on the prediction of hygroscopicity parameters ( $\kappa_{\mathrm{a}, \mathrm{p}}$, Table 1 , Sect. 3.1.2), however, would be small because the size dependence of the composition was generally small. For example, a density fac- tor of 1.5 instead of 1.7 would change the average value of $\kappa_{\mathrm{a}, \mathrm{p}}$ by $\sim 1 \%$ at $\sim 50 \mathrm{~nm}$ and by $\sim 3 \%$ at $\sim 200 \mathrm{~nm}$.

\subsubsection{Volatility measurements (VTDMA)}

A volatility tandem differential mobility analyzer (VTDMA; Philippin et al., 2004) was used to measure the number size distributions of the non-volatile residuals of monodisperse particles that were heated at $300^{\circ} \mathrm{C}(7$ selected diameters in the range of 30-220 nm; time resolution of 1 hour for a complete cycle of 7 diameters). In polluted mega-city air, the material of submicrometer particles that is non-volatile at this temperature is considered to be mostly soot (Smith and O'Dowd, 1996; Burtscher et al., 2001; Kondo et al., 2006; Rose et al., 2006; Frey et al., 2008; Cheng et al., 2009; Wehner et al., 2009), which consists mainly of black or elemental carbon but may also contain some refractory organic matter (Andreae and Gelencsér, 2006; Pöschl, 2005; Sadezky et al., 2005).

In the VTDMA, the measured size distribution of nonvolatile residuals usually separates into two or more modes. The mode which appears in the size range of the initially selected diameter represents particles of low volatility (diameter reduction $<5 \%$ at $300^{\circ} \mathrm{C}$ ), denoted as "LV-particles" for brevity (Cheng et al., 2009; Wehner et al., 2009). The number fraction of LV-particles $\left(\phi_{\mathrm{LV}}\right)$, i.e., their number concentration divided by the total particle number concentration, can be interpreted as the fraction of externally mixed fresh soot particles. Particles with smaller residuals and larger fractions of volatile material (diameter reduction $>5 \%$ ) can be regarded as aged and internally mixed soot particles (Cheng et al., 2009; Wehner et al., 2009).

For each VTDMA measurement cycle, a number size distribution of LV-particles was calculated by multiplying $\phi_{\mathrm{LV}}$ with the particle number $(\mathrm{CN})$ size distribution (measured by the TDMPS) at the diameters selected by the VTDMA $\left(D_{\mathrm{VT}}\right)$. The resulting data points were fitted with a lognormal distribution for inter- and extrapolation.

\subsubsection{Optical measurements (Nephelometer and PAS)}

Total aerosol particle scattering coefficients at three different wavelengths $(\lambda=450 \mathrm{~nm}, 550 \mathrm{~nm}$, and $700 \mathrm{~nm})$ were measured with an integrating nephelometer (Model 3563, TSI) and the aerosol particle absorption coefficient at $532 \mathrm{~nm}$ was determined with a photoacoustic spectrometer (PAS; Desert Research Institute). The time resolution was 2 min for the nephelometer and $10 \mathrm{~s}$ for the PAS. The PAS data was averaged for two minutes to match the time scale of the nephelometer. The single scattering albedo at $\lambda=532 \mathrm{~nm}\left(\omega_{532}\right)$ was calculated from these parameters as described by Garland et al. (2008) and was used to correlate with the CCN properties. For more information on the aerosol optical properties during this campaign see Garland et al. (2008). 


\subsubsection{Particle size distribution measurements (TDMPS)}

The TDMPS (Twin differential mobility particle sizer) used in the PRIDE-PRD2006 campaign was a custom-made instrument from the IfT. In this instrument a combination of two DMAs and two CPCs is used to measure the particle size distribution for a wider size range (here 3-900 nm) than typical DMPS instruments do. For more information on operation, calibration, and uncertainties see Birmili et al. (1999) and Wiedensohler et al. (2010).

\subsubsection{Time resolution and selected periods}

For correlation analyses, the time resolution of the AMS, VTDMA, and optical data sets was adjusted to the time resolution of the CCN data. The AMS or VTDMA data point corresponding to a $\mathrm{CCN}$ data point was chosen to be the one that is closest in time within a time interval of $\pm 10 \mathrm{~min}$ (AMS) or $\pm 60 \mathrm{~min}$ (VTDMA). The optical data were averaged over the time interval of one $\mathrm{CCN}$ measurement $(16 \mathrm{~min})$. If for a $\mathrm{CCN}$ data point no corresponding AMS, VTDMA, or optical data point was available, the $\mathrm{CCN}$ data point was discarded.

Due to the resulting different averaging intervals, the campaign averages calculated in this study may differ from those of Rose et al. (2010a). The CCN data set that was used in Rose et al. (2010a) comprised measurements from 30 June to 30 July 2006. The data set that was taken for the correlation analyses in this study, however, comprised CCN measurements from 12/14 July to 30 July 2006 because of the limited availability of the AMS/VTDMA measurements. Since the second half of July was characterized by two polluted periods (cf. Fig. 5 of Rose et al., 2010a), in this study, the average particle hygroscopicity is lower and the average particle number size distribution is shifted to larger sizes compared to the findings of Rose et al. (2010a).

The highly polluted period of 23 July 00:00 to 26 July 12:59 is referred to as the "biomass burning event (BBE)". As discussed in Part 1 of this study, this period was characterized by intense local biomass burning of plant waste by local farmers, which was visible in the vicinity of the measurement site. As in Rose et al. (2010a), characteristic differences between the BBE and the rest of the campaign are also addressed in this manuscript.

\section{Results and discussion}

\subsection{Aerosol chemical composition and effective hygroscopicity of $\mathrm{CCN}$-active particles}

\subsubsection{Observations and derivation of $\kappa_{\mathrm{org}}$ and $\kappa_{\text {inorg }}$}

Figure 1 shows average aerosol mass size distributions of organic matter and inorganic ions as determined by AMS measurements performed in parallel to the $\mathrm{CCN}$ measurements. Averaged over the campaign excluding the biomass burning
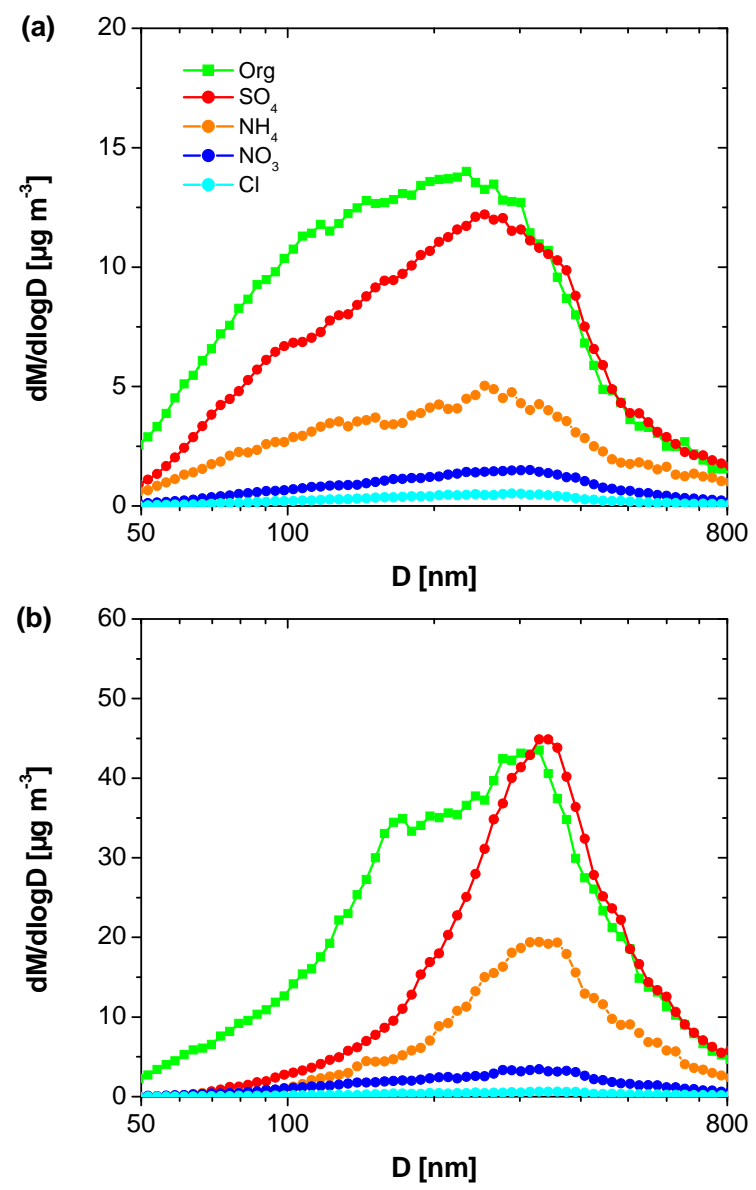

Fig. 1. Mass size distributions of organic and inorganic compounds determined by aerosol mass spectrometry (AMS) averaged (a) over the campaign excluding the biomass burning event (BBE), and (b) over the BBE plotted against the mobility equivalent particle diameter.

event (Fig. 1a), the organic and the sulfate mass size distribution peaked at mobility equivalent diameters of around $220 \mathrm{~nm}$ and $250 \mathrm{~nm}$, respectively. The mass size distributions of the other inorganic ions also peaked around 250 to $300 \mathrm{~nm}$ but at much lower concentration levels. The total mass concentration in the investigated particle size range $(50-850 \mathrm{~nm})$ was $\sim(32 \pm 29) \mu \mathrm{g} \mathrm{m}^{-3}$, and the contributions of individual components are listed in Table 2.

During the biomass burning event (BBE, Fig. 1b), the mass concentrations of all components were by a factor of $\sim 2$ higher than during the rest of the campaign. The mass size distributions of the inorganic ions were narrower with the peak shifted to 300 to $350 \mathrm{~nm}$. The mass size distribution of organic matter, however, exhibited two separate peaks around $170 \mathrm{~nm}$ and $300 \mathrm{~nm}$, respectively. In the small particle size range $(<\sim 200 \mathrm{~nm})$ only the organic mass concentration increased during the BBE, whereas the inorganic ion concentrations remained almost the same as during the rest of the campaign. 

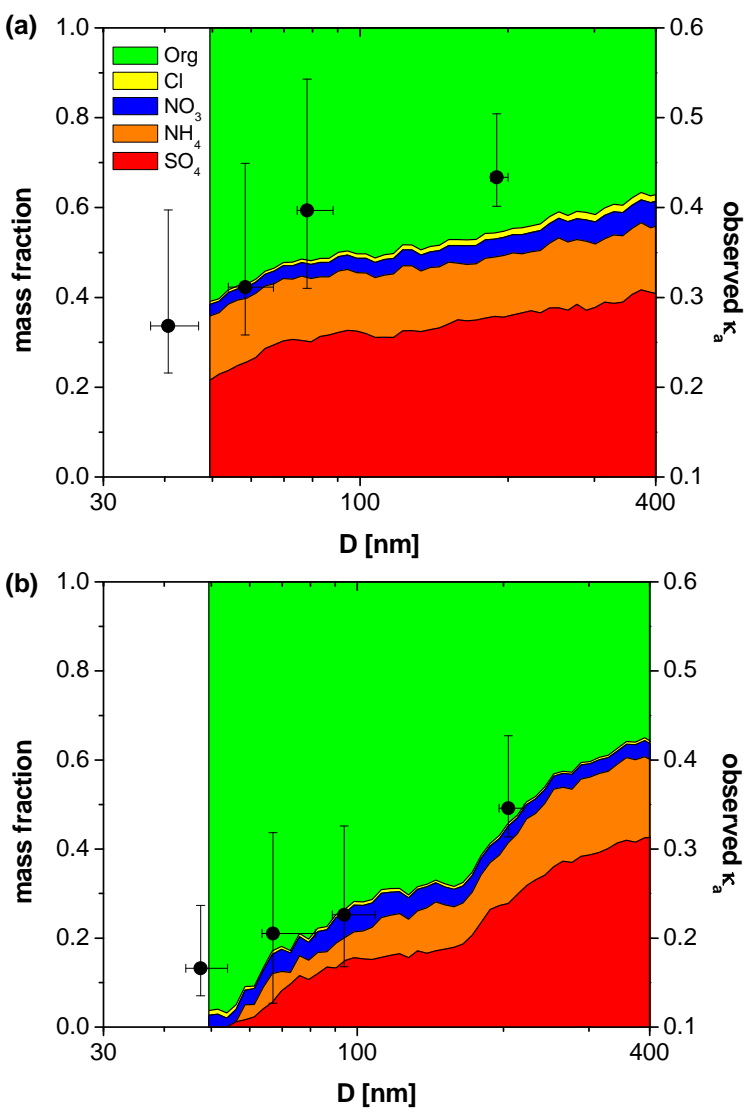

Fig. 2. Size distributions of mass fractions of organic and inorganic compounds (colored areas) determined by the AMS, and observed effective hygroscopicity parameter of $\mathrm{CCN}$-active particles $\left(\kappa_{\mathrm{a}}\right.$, data points) averaged (a) over the campaign excluding the BBE, and (b) over the BBE. Data points are median values and error bars indicate inter-quartile ranges.

Figure 2 depicts the size distributions of the mass fractions of the individual chemical components averaged over the campaign excluding the BBE and averaged over the BBE. For both the averaging periods, the ratio of inorganic to organic mass increased with particle size. The larger particles $(>\sim 200 \mathrm{~nm})$ exhibited an inorganic mass fraction of 50-60\% throughout the whole campaign, whereas for the smaller particles $(50-200 \mathrm{~nm})$ the mass fractions during the BBE differed a lot from those during the rest of the campaign (increasing organic mass fraction with decreasing size, up to almost $100 \%$ during the BBE and up to only $\sim 60 \%$ during the rest of the campaign).

In the same figure, the measured effective hygroscopicity parameter $\kappa_{\mathrm{a}}$ (characteristic for the $\mathrm{CCN}$-active particles) is plotted versus the activation diameter $D_{\mathrm{a}}$ (Table 1$)$. The scale of the $\kappa$-axis is chosen so that it matches the scale of the mass fraction according to the expected relationship between hygroscopicity and chemical composition, that is $\kappa=0.1$ for
Table 2. Average mass concentrations of organic matter and inorganic ions (arithmetic mean values \pm standard deviation) as obtained from AMS measurements integrated over a mobility equivalent particle size range of $50-850 \mathrm{~nm}$ for the entire campaign, for the biomass burning event (BBE), and for the campaign excluding the BBE.

\begin{tabular}{|c|c|c|c|}
\hline \multirow[t]{2}{*}{ Component } & \multicolumn{3}{|c|}{ Mass concentration $\left[\mu \mathrm{g} \mathrm{m}^{-3}\right]$} \\
\hline & $\begin{array}{c}\text { Entire } \\
\text { campaign }\end{array}$ & BBE & $\begin{array}{l}\text { Campaign } \\
\text { excl. BBE }\end{array}$ \\
\hline Org & $16.1 \pm 13.3$ & $32.5 \pm 19.8$ & $12.8 \pm 8.3$ \\
\hline $\mathrm{SO}_{4}$ & $12.8 \pm 9.2$ & $20.7 \pm 7.6$ & $11.3 \pm 8.7$ \\
\hline $\mathrm{NH}_{4}$ & $6.1 \pm 7.2$ & $9.9 \pm 4.5$ & $5.4 \pm 7.3$ \\
\hline $\mathrm{NO}_{3}$ & $1.8 \pm 1.9$ & $3.0 \pm 2.4$ & $1.5 \pm 1.6$ \\
\hline $\mathrm{Cl}$ & $0.9 \pm 3.5$ & $1.8 \pm 4.3$ & $0.7 \pm 3.3$ \\
\hline Total & $37.8 \pm 35.0$ & $67.9 \pm 38.7$ & $31.7 \pm 29.3$ \\
\hline
\end{tabular}

aerosol that consists only of organic material and $\kappa=0.6$ for aerosol consisting of only inorganic material. The approximate average organic $\kappa$ value of 0.1 is consistent with earlier studies (e.g., Gunthe et al., 2009; Dusek et al., 2010; King et al., 2010; Pöschl, 2011, and references therein) and within the characteristic range for individual organic compounds going from zero for insoluble species to $\sim 0.3$ for small soluble molecules such as oxalic acid (Petters and Kreidenweis, 2007; Mikhailov et al., 2009).

Figure $2 \mathrm{~b}$ shows that during the BBE, the $\kappa$ data points follow the border between inorganic and organic mass fraction. This can be expected when assuming a simple approximative mixing rule for $\kappa$ (Gunthe et al., 2009; Dusek et al., 2010). The predicted $\kappa_{\mathrm{a}}$ value for particles of a certain size is:

$\kappa_{\mathrm{a}, \mathrm{p}} \approx \kappa_{\text {org }} \cdot f_{\text {org }}+\kappa_{\text {inorg }} \cdot f_{\text {inorg }} \approx 0.1 \cdot f_{\text {org }}+0.6 \cdot f_{\text {inorg }}$

with $\kappa_{\text {org }}$ and $\kappa_{\text {inorg }}$ being the effective hygroscopicity parameters for organic and inorganic components, and $f_{\text {org }}$ and $f_{\text {inorg }}$ being the organic and inorganic mass fractions at particle diameter $D$, respectively. By definition, the mixing rule for the $\kappa$ values of different particle components refers to volume fractions, but mass fractions can be used for first-order approximations (Kreidenweis et al., 2008, 2009) assuming that the densities of individual components are similar to the overall particle density, which is reasonable for particles consisting mostly of organics and sulfate (Gunthe et al., 2009).

In contrast, the $\kappa$ values in the plot of the campaign average excluding the BBE (Fig. 2a) did not follow the line between inorganic and organic mass fraction as well. The hygroscopicity increased with particle size as did the inorganic mass fraction, but for $D>60 \mathrm{~nm}$ the observed $\kappa_{\mathrm{a}}$ was higher than the expected hygroscopicity. This inconsistency can be partly attributed to the large number of data points with low mass concentrations that go into the campaign average and make the AMS data less reliable. For the BBE, this is not the case since the mass concentrations were generally much higher. 


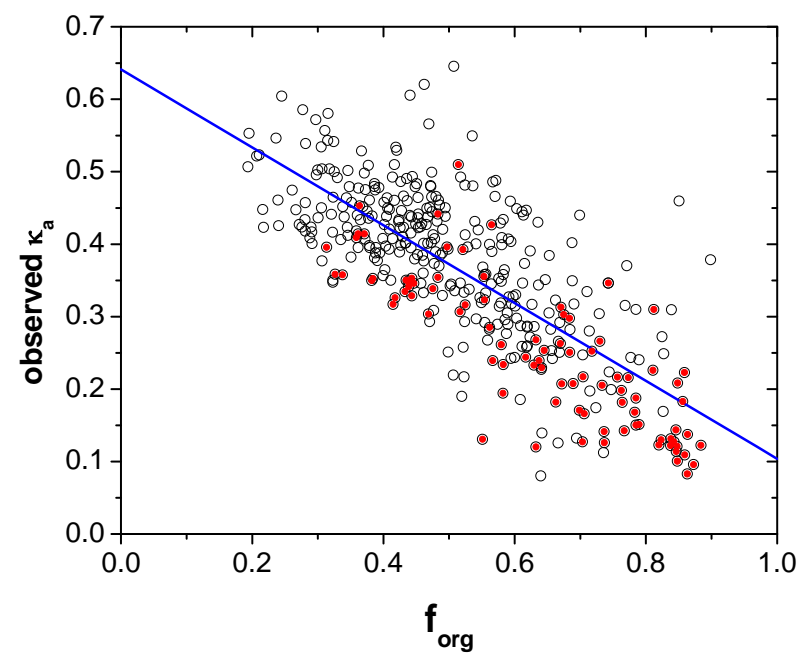

Fig. 3. Correlation between the observed effective hygroscopicity parameter of $\mathrm{CCN}$-active particles $\left(\kappa_{\mathrm{a}}\right)$ and the organic mass fraction $\left(f_{\text {org }}\right)$ determined by size-resolved AMS measurements for the entire campaign. Data points at which $m_{\mathrm{D}}<1 \mu \mathrm{g} \mathrm{m}^{-3}$ are excluded. Red dots indicate the data points measured during the BBE. The blue line is a linear least squares fit with the following equation, correlation coefficient, and number of data points: $y=0.64-0.54 \cdot x, R^{2}=0.57, n=379$.

To investigate the relationship between chemical composition and hygroscopicity of the aerosol particles more specifically, we correlated the observed $\kappa_{\mathrm{a}}$ values obtained for every measured $\mathrm{CCN}$ efficiency spectrum with the measured organic mass fraction $\left(f_{\text {org }}\right)$. When we performed this for all data points only a poor correlation could be found $\left(R^{2}=0.44\right)$. This was most likely due to the large amount of data points for which the mass within the integration interval $\left(m_{\mathrm{D}}\right.$, see Sect. 2.2.3) was very low (40\% of the data points exhibited $m_{\mathrm{D}}<1 \mu \mathrm{g} \mathrm{m}^{-3}$ ), which negatively impacted the reliability of $f_{\text {org. }}$. The correlation shown in Fig. 3 consists therefore only of data points with $m_{\mathrm{D}} \geq 1 \mu \mathrm{g} \mathrm{m}^{-3}$, which improved the fit $\left(R^{2}=0.57, n=379\right)$. Extrapolation of the fit line to $f_{\text {org }}=0$ yielded $\kappa_{\text {inorg }}=0.64 \pm 0.01$ for the inorganic fraction, which is characteristic for ammonium sulfate and related compounds (Petters and Kreidenweis, 2007; Rose et al., 2008). Extrapolation of the fit line to $f_{\text {org }}=1$ yielded $\kappa_{\text {org }}=0.10 \pm 0.02$ for the organic fraction. This is similar to the average hygroscopicity parameters found in field measurements and chamber studies of secondary organic aerosol (SOA) (King et al., 2009; Gunthe et al., 2009; Dusek et al., 2010). Apparently, the differences between more and less water-soluble and hygroscopic organic compounds present in SOA and primary organic aerosols (POA, e.g., carboxylic acids, levoglucosan, polyfunctional aliphatic and aromatic hydrocarbons, proteins) tend to cancel out in the course of atmospheric mixing and chemical aging.

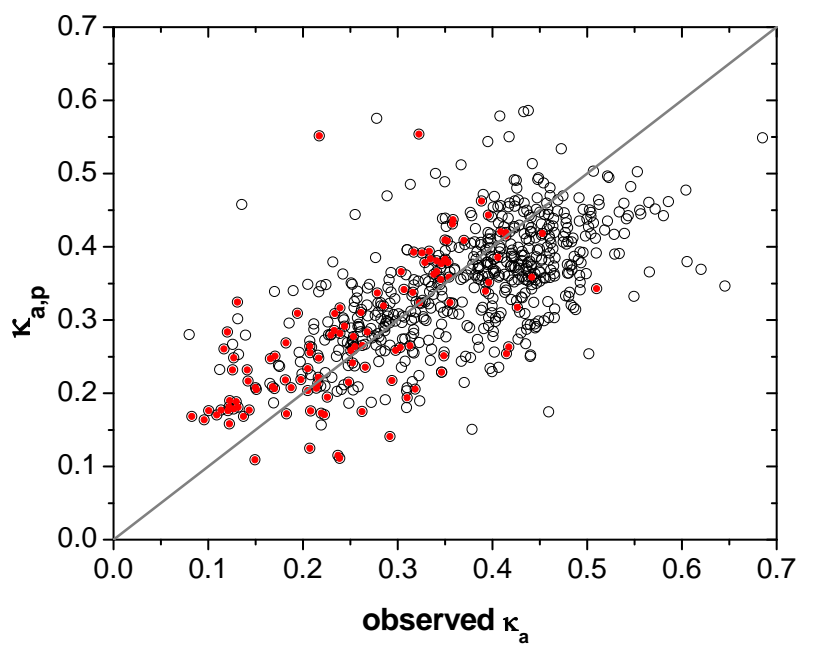

Fig. 4. Effective hygroscopicity parameters predicted from the organic and inorganic mass fractions determined by AMS measurements $\left(\kappa_{\mathrm{a}, \mathrm{p}}\right.$, Eq. (1)) plotted against the values obtained from the $\mathrm{CCN}$ measurements $\left(\kappa_{\mathrm{a}}\right)$ observed for the entire campaign. Note that the data points at which $m_{\mathrm{D}}<1 \mu \mathrm{g} \mathrm{m}{ }^{-3}$ are included. Red dots indicate the data points measured during the BBE. The diagonal grey line indicates the $1: 1$ ratio.

\subsubsection{Prediction of $\kappa_{\mathrm{a}}$ and $N_{\mathrm{CCN}, \mathrm{S}}$}

In Fig. 4 the $\kappa$ values predicted from the AMS measurement data $\left(\kappa_{\mathrm{a}, \mathrm{p}}\right.$, calculated from Eq. 1) are plotted against the $\kappa$ values derived from the 3-parameter CDF fits to the measured CCN efficiency spectra (observed $\kappa_{\mathrm{a}}$ ). Note that in this plot all data points are shown including the ones for which $m_{\mathrm{D}}<1 \mu \mathrm{g} \mathrm{m}^{-3}$. The equation of a linear fit through the data points would be $y=0.53 x+0.15$ and as expected from the above findings, $\kappa_{\mathrm{a}, \mathrm{p}}$ and the observed $\kappa_{\mathrm{a}}$ exhibit a weak correlation $\left(R^{2}=0.44\right)$ due to numerous outliers. They mostly correspond to values for which $m_{\mathrm{D}}<1 \mu \mathrm{g} \mathrm{m}^{-3}$, which suggests that the outliers can be mainly attributed to unreliable AMS data due to low mass concentrations. They may also result from different and temporally varying molecular composition and hygroscopic properties of the organic fraction of the investigated aerosols. In the most frequent range of $\kappa$ values $(0.25$ to $0.55 ; \sim 80 \%$ of all data points), the predicted values deviate from the observed ones on average by less than $20 \%$. For smaller values, $\kappa_{\mathrm{a}, \mathrm{p}}$ is generally larger than the observed $\kappa_{\mathrm{a}}$ (by up to $100 \%$ and more), whereas for larger values it is mainly smaller (by up to a few tens of percent).

For each data point of Fig. 4, the total CCN number concentration $\left(N_{\mathrm{CCN}, \mathrm{S}}\right)$ was calculated by integrating the measured $\mathrm{CN}$ size distribution above the critical dry particle diameter for $\mathrm{CCN}$ activation that corresponds to the given values of $\kappa_{\mathrm{a}, \mathrm{p}}$ and $S$. In spite of the low correlation between the predicted and observed $\kappa_{\mathrm{a}}$, the mean relative deviations 
Table 3. Arithmetic means of the observed $\kappa_{\mathrm{a}}$ and $N_{\mathrm{CCN}, \mathrm{S}}$ values, and characteristic deviations between predicted values $\left(\kappa_{\mathrm{a}, \mathrm{p}}\right.$ and $N_{\mathrm{CCN}, \mathrm{S}, \mathrm{p}}$ ) and those observed (relative bias and total relative deviation, including systematic and statistical errors) for the entire campaign. $n_{\kappa}$ and $n_{\mathrm{N}}$ are the number of data points that are contained in the averages of $\kappa_{\mathrm{a}, \mathrm{p}}$ and $N_{\mathrm{CCN}, \mathrm{S}, \mathrm{p}}$, respectively.

\begin{tabular}{|c|c|c|c|c|c|c|c|c|c|c|}
\hline \multirow{2}{*}{$\begin{array}{l}S \\
{[\%]}\end{array}$} & \multirow[t]{2}{*}{$\kappa_{\mathrm{a}}$} & \multicolumn{2}{|c|}{$\kappa_{\mathrm{a}, \mathrm{p}}$, Eq. $(1)$} & \multirow[t]{2}{*}{$n_{\kappa}$} & \multirow{2}{*}{$\begin{array}{l}N_{\mathrm{CCN}, \mathrm{S}} \\
{\left[\mathrm{cm}^{-3}\right]}\end{array}$} & \multicolumn{2}{|c|}{$N_{\mathrm{CCN}, \mathrm{S}, \mathrm{p}}$ with $\kappa_{\mathrm{a}, \mathrm{p}}$} & \multicolumn{2}{|c|}{$N_{\mathrm{CCN}, \mathrm{S}, \mathrm{p}}$ with $\kappa=0.3$} & \multirow[t]{2}{*}{$n_{\mathrm{N}}$} \\
\hline & & $\begin{array}{r}\text { rel. bias } \\
{[\%]}\end{array}$ & $\begin{array}{r}\text { rel. dev. } \\
{[\%]}\end{array}$ & & & $\begin{array}{r}\text { rel. bias } \\
{[\%]}\end{array}$ & $\begin{array}{r}\text { rel. dev. } \\
{[\%]}\end{array}$ & $\begin{array}{r}\text { rel. bias } \\
{[\%]}\end{array}$ & $\begin{array}{r}\text { rel. dev. } \\
{[\%]}\end{array}$ & \\
\hline 0.068 & 042 & -7.6 & 14.3 & 229 & 1130 & +34.0 & 34.5 & +7.9 & 19.1 & 176 \\
\hline 0.27 & 0.36 & -2.3 & 20.5 & 229 & 6529 & +14.0 & 16.0 & +11.6 & 19.6 & 179 \\
\hline 0.47 & 0.28 & +15.6 & 29.1 & 173 & 8748 & +13.1 & 14.5 & +15.3 & 16.9 & 151 \\
\hline all & 0.36 & +0.7 & 20.6 & 631 & & +20.7 & 22.0 & +11.4 & 18.6 & 506 \\
\hline
\end{tabular}

between the $N_{\mathrm{CCN}, \mathrm{S}}$ predicted on the basis of $\kappa_{\mathrm{a}, \mathrm{p}}\left(N_{\mathrm{CCN}, \mathrm{S}, \mathrm{p}}\right.$, Eq. 1, Table 3) and the observed values of $N_{\mathrm{CCN}, \mathrm{S}}$ were mostly less than $20 \%$ with a positive bias on average. This confirms the relatively low sensitivity of $N_{\mathrm{CCN}, \mathrm{S}, \mathrm{p}}$ against $\kappa$ as discussed already in Rose et al. (2010a).

In Table 3 is shown that the over-prediction of $N_{\mathrm{CCN}, \mathrm{S}, \mathrm{p}}$ compared to the observed $N_{\mathrm{CCN}, \mathrm{S}}$ becomes larger with decreasing supersaturation, which has been also found, e.g., in Rose et al. (2010a), Wex et al. (2010), and Gunthe et al. (2009). This confirms that the prediction of $N_{\mathrm{CCN}, \mathrm{S}}$ is generally less robust at low $S$, which is due to the enhanced error sensitivity caused by the steep slope of the aerosol size distribution typically observed at the large activation diameters corresponding to low supersaturations (Ervens et al., 2007) and also to the stronger influence of externally mixed weakly CCN-active particles at large $D$ and low $S$ (Figs. 2-3 of Rose et al., 2010a). Alternatively or in addition the changing degree of over-prediction with changing supersaturation may be caused by different solubility of the particles and surface tension effects.

Table 3 also shows the $N_{\mathrm{CCN}, \mathrm{S}, \mathrm{p}}$ calculated for the same data set using a constant $\kappa$ of 0.3 (which is the campaign average value for $\kappa_{\mathrm{t}}$ (Table 1)) similar to the analysis performed by Rose et al. (2010a). It is remarkable that the average deviations between predicted and observed values of $N_{\mathrm{CCN}, \mathrm{S}}$ are lower for the constant $\kappa(19 \%)$ than when using the composition dependent $\kappa_{\mathrm{a}, \mathrm{p}}(22 \%)$, especially for the smallest supersaturation ( $19 \%$ versus $35 \%$ relative deviation). The same result was found by Gunthe et al. (2009) for a data set from pristine tropical rainforest air of Amazonia. It confirms that $\kappa_{\mathrm{a}, \mathrm{p}}$ is not sufficient to predict $N_{\mathrm{CCN}, \mathrm{S}}$ well, if a significant fraction of externally mixed weakly $\mathrm{CCN}$-active particles is present as observed for this data set. The parameter $\kappa_{\mathrm{a}}$ tends to overestimate the effective overall hygroscopicity of the ensemble of aerosol particles, because it describes only the hygroscopicity of the internally mixed $\mathrm{CCN}$-active particles but does not account for the low hygroscopicity of the externally mixed weakly $\mathrm{CCN}$-active particles in the ensemble (Rose et al., 2010a). This is also in accordance with Wex et al. (2010) who concluded that the hygroscopicity derived from AMS data alone is not sufficient for accurate prediction of $N_{\mathrm{CCN}, \mathrm{S}}$, and that it is important to determine the separate fraction of aerosol particles with low hygroscopicity.

\subsection{CCN activity of low volatility particles (externally mixed soot)}

\subsubsection{Observations and derivation of $\kappa_{\mathrm{LV}}$}

As stated in Rose et al. (2010a), the CCN efficiency spectra observed at low supersaturations $(S \leq 0.27 \%)$ did not reach full activation. This indicates the presence of externally mixed weakly $\mathrm{CCN}$-active particles which were of much lower hygroscopicity and therefore activated only at higher supersaturation (Su et al., 2010).

Figure 5 shows the non-activated fraction (1-MAF $\mathrm{F}_{\mathrm{f}}$ Table 1) plotted against $D_{\mathrm{a}}+3 \sigma_{\mathrm{a}}$, which is the smallest particle size at which the $C C N$ spectrum reaches $M_{A F}$. In the same figure, the number fraction of low volatility particles $\left(\phi_{\mathrm{LV}}\right)$ is plotted against the initial diameter selected by the VTDMA $\left(D_{\mathrm{VT}}\right)$. From 30 to $220 \mathrm{~nm}, \phi_{\mathrm{LV}}$ increased from 0.02 to 0.25 . The non-activated fraction, $1-\mathrm{MAF}_{\mathrm{f}}$, followed almost exactly the same trend and increased from 0.05 to 0.27 over the diameter range of 55 to $230 \mathrm{~nm}$. This coincidence suggests that the non-activated fraction may consist of fresh soot particles, as discussed and corroborated in the following.

Figure 6 depicts the campaign median number size distributions of total $\mathrm{CN}$, of the low volatility ( $\mathrm{LV}-$ ) particles, and of the non-activated particles at $S=0.068 \%$ (CCN size distribution at $S=0.068 \%$ subtracted from $\mathrm{CN}$ size distribution). The $\mathrm{CN}$ size distribution is monomodal and peaks around $90 \mathrm{~nm}$ with a maximum value of $20000 \mathrm{~cm}^{-3}$ per logarithmic decade of particle diameter. The number size distribution of LV-particles peaks around $110 \mathrm{~nm}$ with a maximum value of $2500 \mathrm{~cm}^{-3}$. The size distribution of the non-activated particles at $S=0.068 \%$ follows for particles larger than $D_{\mathrm{a}}+3 \sigma_{\mathrm{a}}$ exactly the distribution of the LVparticles and for particles smaller than $D_{\mathrm{a}}-3 \sigma_{\mathrm{a}}$ the distribution of $\mathrm{CN}$. In the range between $D_{\mathrm{a}}+3 \sigma_{\mathrm{a}}$ and $D_{\mathrm{a}}-3 \sigma_{\mathrm{a}}$ (indicated by the dotted blue vertical lines), the particle activation occurs and thus the size distribution of non-activated 


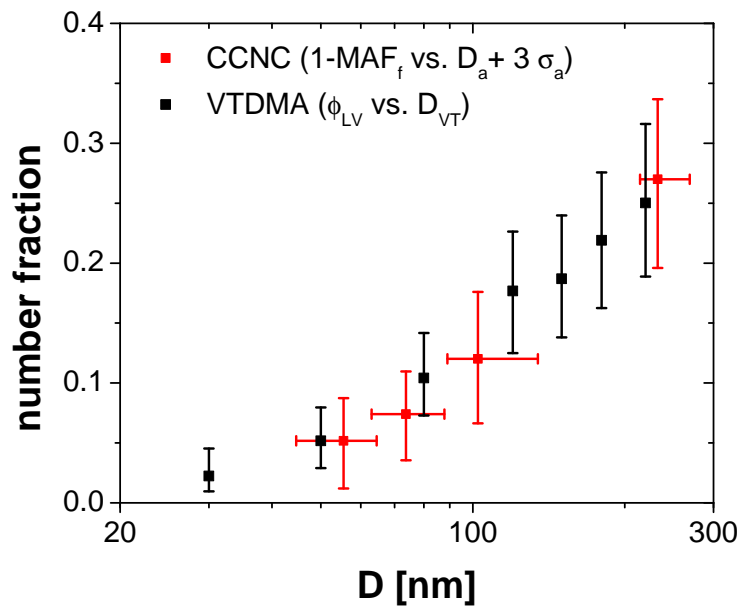

Fig. 5. Black symbols: number fraction of particles with low volatility $\left(\phi_{\mathrm{LV}}\right)$ plotted versus the particle size selected by the VTDMA $\left(D_{\mathrm{VT}}\right)$. Red symbols: number fraction of particles that are not $\mathrm{CCN}$-active within the investigated size range $\left(1-\mathrm{MAF}_{\mathrm{f}}\right)$ plotted versus the smallest particle size at which the $\mathrm{CCN}$ spectrum reaches $\operatorname{MAF}_{\mathrm{f}}\left(D_{\mathrm{a}}+3 \sigma_{\mathrm{a}}\right)$; each symbol stands for each supersaturation. Symbols are median values throughout the campaign, error bars extend to lower and upper quartiles.

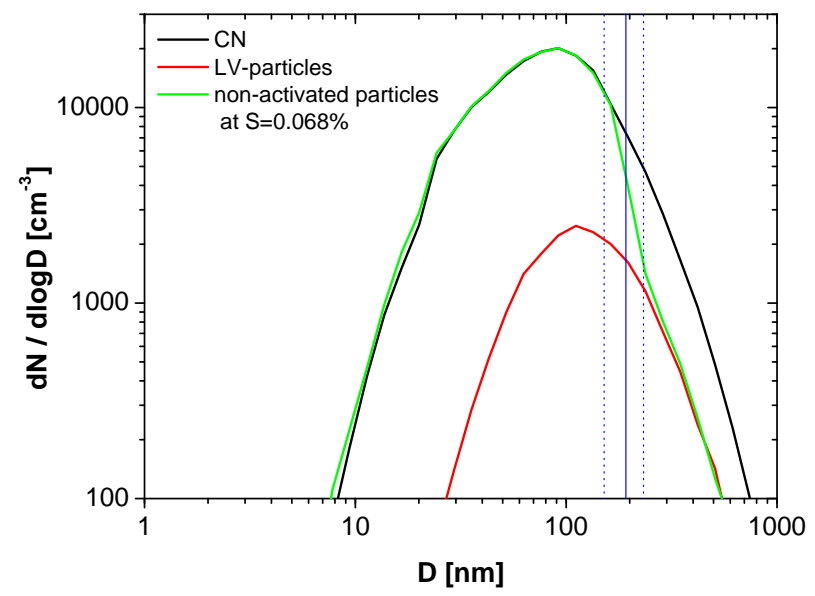

Fig. 6. Campaign median number size distributions of CN (black), of the externally mixed LV-particles (red), and of the non-activated particles at $S=0.068 \%$ (green). The blue solid line indicates where the median activation diameter $D_{\mathrm{a}}$ is located. The blue dashed lines denote the location of $D_{\mathrm{a}}-3 \sigma_{\mathrm{a}}$ and $D_{\mathrm{a}}+3 \sigma_{\mathrm{a}}$.

particles jumps from following the LV-particle size distribution to following the $\mathrm{CN}$ size distribution. This figure indicates that the particles larger than $\sim 250 \mathrm{~nm}$ that do not activate at $S=0.068 \%$ represent the LV-particles measured by the VTDMA, which can be regarded as fresh externally mixed soot particles. They do not activate at this supersaturation because they are not sufficiently hygroscopic. The particles smaller than $\sim 250 \mathrm{~nm}$ are too small to activate even if they are more hygroscopic.
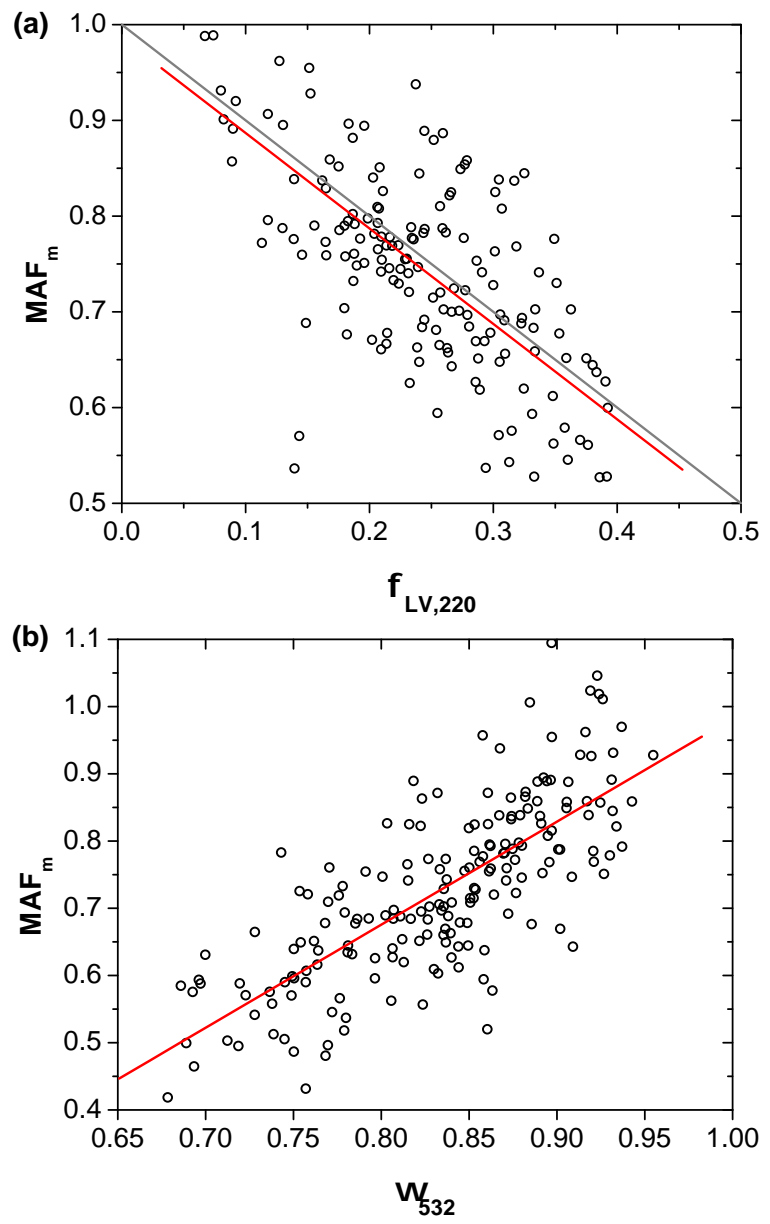

Fig. 7. Correlation between (a) the number fraction of activated particles at $270 \mathrm{~nm}\left(\mathrm{MAF}_{\mathrm{m}}\right)$ for $S=0.068 \%$ and the number fraction of LV-particles at $220 \mathrm{~nm}\left(\phi_{\mathrm{LV}, 220}\right)$ and (b) $\mathrm{MAF}_{\mathrm{m}}$ for $S=0.068 \%$ and the single scattering albedo $\left(\omega_{532}\right)$. The red lines are linear least squares fit lines through the data points with the following equation, correlation coefficient, and number of data points: (a) $y=$ $0.986-0.997 x, R^{2}=0.47, n=170$; and (b) $y=-0.55+1.53 x$, $R^{2}=0.57, n=192$. The grey line in (a) is to guide the eye.

In Fig. 7a the number fraction of $270 \mathrm{~nm}$ particles that activate at $S=0.068 \%\left(\mathrm{MAF}_{\mathrm{m}}\right)$ is plotted versus the number fraction of LV-particles at $220 \mathrm{~nm}$ as determined by the VTDMA $\left(\phi_{\mathrm{LV}, 220}\right)$. In the CCN measurements, the $270 \mathrm{~nm}$ size bin was the largest size selected. For all supersaturations, the measured $\mathrm{CCN}$ efficiency spectra were not anymore raising at this size but reached a plateau level $\left(\mathrm{MAF}_{\mathrm{m}}\right.$; cf. Fig. 3 of Rose et al., 2010a). In the VTDMA measurements, the $220 \mathrm{~nm}$ size bin is the largest size selected. It can be assumed that $\phi_{\mathrm{LV}}$ measured at this size is comparable to $\phi_{\mathrm{LV}}$ at $270 \mathrm{~nm}$, as seen from comparing the LV-particle size distribution with the $\mathrm{CN}$ size distribution (Fig. 6). 
The correlation plot in Fig. 7a shows that $\mathrm{MAF}_{\mathrm{m}}$ decreased with increasing $\phi_{\mathrm{LV}}$ with a linear least squares fit (red line) that is close to the 1:(-1) line. This is another indicator that the particles with a size of $270 \mathrm{~nm}$ that did not activate at $S=$ $0.068 \%$ corresponded to the LV-particles at that size. Since they were not activated at $0.068 \%$ supersaturation they must have had a hygroscopicity of less than $\kappa=0.15$ (Eq. (2) of Rose et al., 2010a).

Figure $7 \mathrm{~b}$ shows that $\mathrm{MAF}_{\mathrm{m}}$ also correlated with the single scattering albedo of the investigated aerosol in the green wavelength range $\left(\omega_{532} ; R^{2}=0.57\right)$. $\omega_{532}$ is inversely related to the proportion of light absorbing material in the aerosol, which in the case of an urban-derived aerosol consists mostly of soot (black carbon). This supports that the non-activated particle fraction is related to the soot content of the aerosol.

Assuming that the difference between $\mathrm{MAF}_{\mathrm{m}}$ and (1$\left.\phi_{\mathrm{LV}, 220}\right)$ approximately corresponds to the fraction of LVparticles that can be activated at a given supersaturation, we used the following equation to calculate $\mathrm{CCN}$ efficiencies for the LV-particles (that is, a CCN efficiency spectrum for fresh soot particles):

$$
\left(\frac{N_{\mathrm{CCN}}}{N_{\mathrm{CN}}}\right)_{\mathrm{LV}}=\frac{\mathrm{MAF}_{\mathrm{m}}-\left(1-\phi_{\mathrm{LV}, 220}\right)}{\phi_{\mathrm{LV}, 220}}
$$

A similar approach has been already used by Kuwata et al. (2007).

In Fig. 8a, the campaign median values of the $\mathrm{CCN}$ efficiency of LV-particles calculated according to Eq. (2) are plotted against the supersaturation. The data point at $S=$ $0.068 \%$ is slightly negative. The deviation from zero is within the range of measurement uncertainties, and it might also be influenced by deviations from the assumption that the LV-particles correspond to the non-activated particles. At $S=0.87 \%$, the CCN efficiency of the LV-particles approaches unity. To obtain an effective average value for the critical supersaturation of $\mathrm{CCN}$ activation, the data points were fitted with a 3-parameter $\mathrm{CDF}$, which yielded a midpoint value (critical supersaturation) of $S_{\mathrm{c}}=0.26 \%$ corresponding to a $\kappa$ value of 0.009 (Eq. (2) of Rose et al., 2010a). An alternative fit through all individual data points of the campaign (non-averaged) yielded $S_{\mathrm{c}}=0.25 \%$ corresponding to $\kappa=0.010$.

Due to the few available levels of supersaturation, the CDF fits are not very well constrained, but the range of possible midpoint values is limited to $S_{\mathrm{c}}=0.068 \%-0.27 \%$ corresponding to $\kappa=0.15-0.008$. Hence, we applied linear interpolation between these two data points as an alternative approach for calculating approximate midpoint values of $S_{\mathrm{c}}=0.22 \%$ and $\kappa=0.013\left(\right.$ at $\left.\left(N_{\mathrm{CCN}} / N_{\mathrm{CN}}\right)_{\mathrm{LV}}=0.5\right)$.

From both of these fits (CDF and linear fit), an approximate average value for the effective hygroscopicity of fresh soot particles of $\kappa_{\mathrm{LV}} \approx 0.01$ can be derived from our $\mathrm{CCN}$ and VTDMA measurement data. This value is slightly lower but close to the ones that Wex et al. (2010) derived from
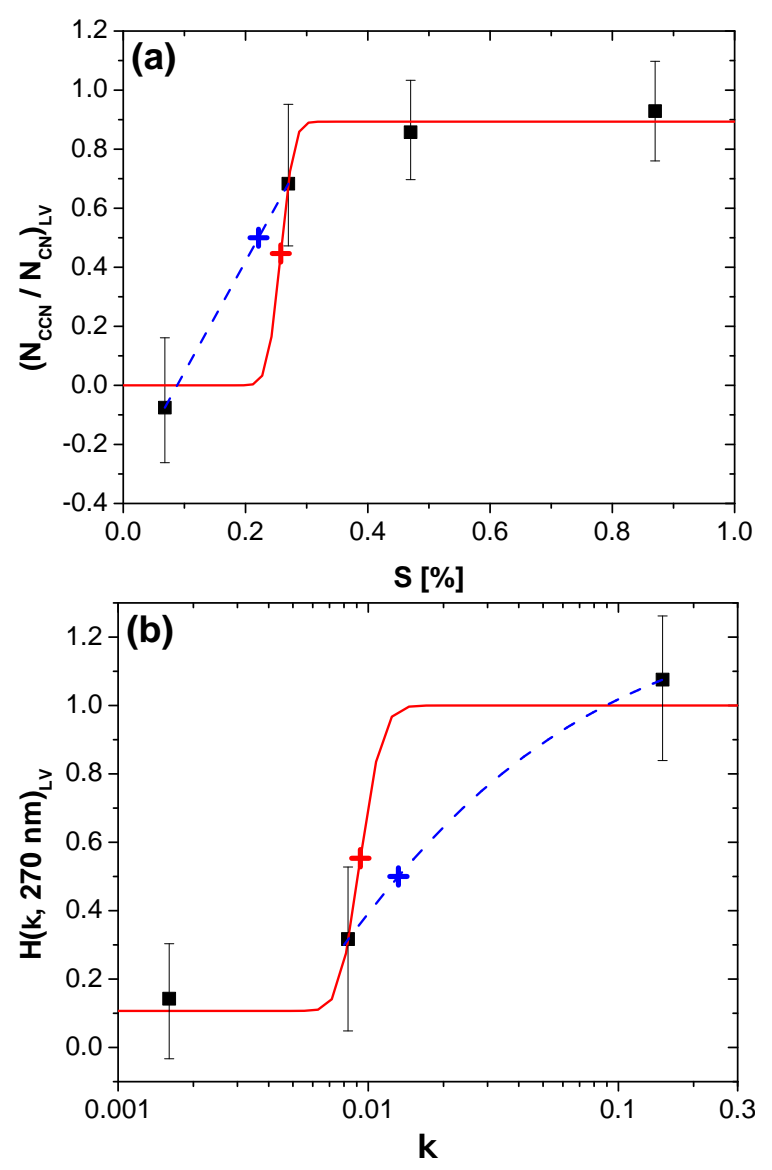

Fig. 8. (a) $\mathrm{CCN}$ efficiencies plotted against supersaturation and (b) cumulative hygroscopicity distribution for LV-particles of $270 \mathrm{~nm}$ plotted against the hygroscopicity parameter, $\kappa$. Black data points are campaign median values of the data points calculated by Eq. (2), error bars extend to their lower and upper quartiles. The red line is a 3-parameter CDF fit to the black data points and the red cross is the point of (a) the midpoint supersaturation and (b) the median value of $\kappa$ obtained from the fit. The dashed blue line represents an alternative approach (linear interpolation) for calculating approximate midpoint values (blue cross).

hygroscopicity tandem DMA (HTDMA) data for the low hygroscopicity particle fraction in urban and rural aerosols $(\kappa=0.02-0.04)$.

Figure $8 \mathrm{~b}$ shows the cumulative hygroscopicity distribution for the LV-particles at $270 \mathrm{~nm}, H(\kappa, 270 \mathrm{~nm})_{\mathrm{LV}}=1-$ $\left(N_{\mathrm{CCN}} / N_{\mathrm{CN}}\right)_{\mathrm{LV}}$. As explained in Su et al. $(2010), H(\kappa, D)$ corresponds to the fraction of particles with an effective hygroscopicity parameter smaller than the $\kappa$ value plotted on the x-axis. The $S$ values of Fig. 8 a were converted into the corresponding $\kappa$ values of Fig. 8b using Eq. (2) of Rose et al. (2010a). The figure illustrates the spread of the LV-particles' effective hygroscopicity with a median value near $\kappa_{\mathrm{LV}} \approx 0.01$, which will be used for further analyses. 

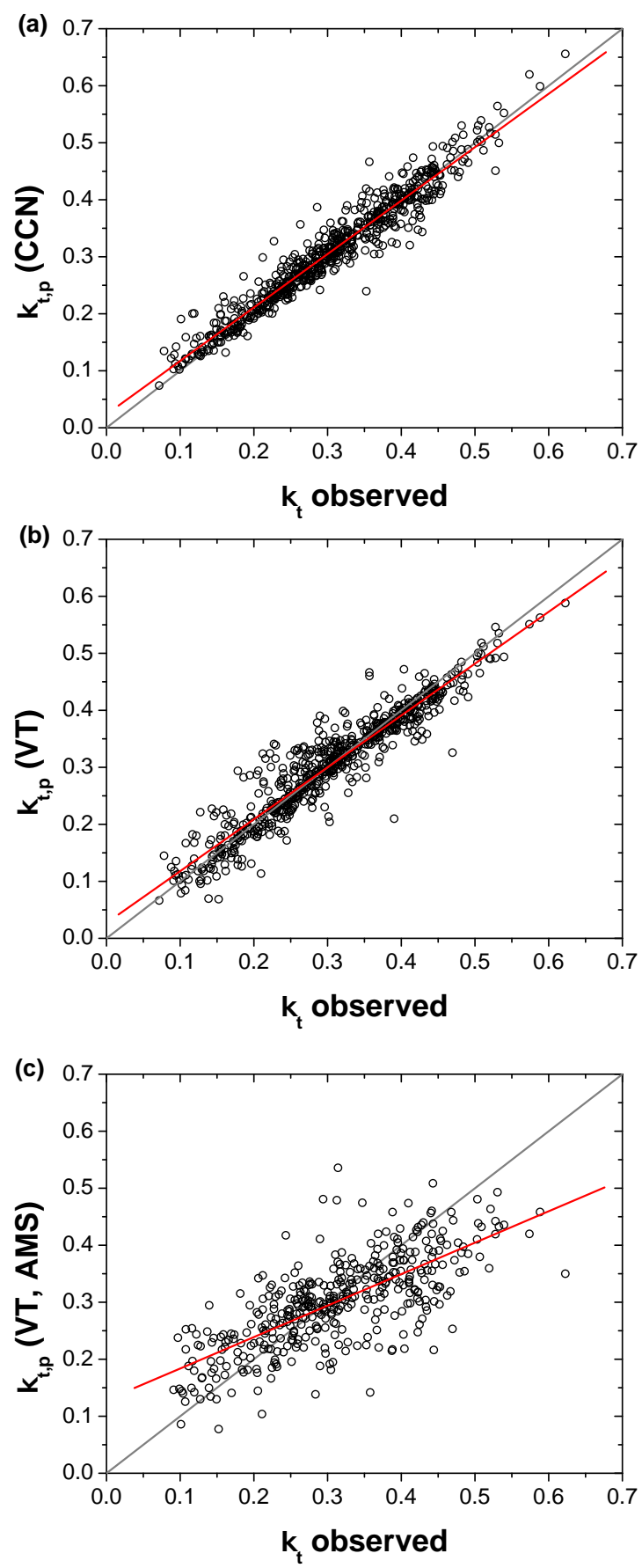

Fig. 9. Correlation plot of (a) the predicted $\kappa_{\mathrm{t}}$ as calculated from the $\mathrm{CCN}$ data $\left(\mathrm{MAF}_{\mathrm{m}}\right)$ and Eq. $(3)\left(\kappa_{\mathrm{t}, \mathrm{p}}(\mathrm{CCN})\right)$ versus the observed $\kappa_{\mathrm{t}}$, (b) the predicted $\kappa_{\mathrm{t}}$ as calculated from the VTDMA data $\left(\phi_{\mathrm{LV}, 220}\right)$ and Eq. (4) $\left(\kappa_{\mathrm{t}, \mathrm{p}}(\mathrm{VT})\right)$ versus the observed $\kappa_{\mathrm{t}}$, and (c) the predicted $\kappa_{\mathrm{t}}$ as calculated from the VTDMA data $\left(\phi_{\mathrm{LV}, 220}\right)$, AMS data $\left(f_{\text {org }}\right.$, $\left.f_{\text {inorg }}\right)$, and Eq. (5) $\left(\kappa_{\mathrm{t}, \mathrm{p}}(\mathrm{VT}, \mathrm{AMS})\right)$ versus the observed $\kappa_{\mathrm{t}}$. The grey lines are the 1:1 lines and the red lines are linear least squares fit lines through the data points with the following equation, correlation coefficient, and number of data points: (a) $y=0.02+0.94 x$, $R^{2}=0.94, n=656$; (b) $y=0.03+0.91 x, R^{2}=0.89, n=656$; and (c) $y=0.13+0.55 x, R^{2}=0.52, n=409$.

\subsubsection{Prediction of $\kappa_{\mathrm{t}}$ and $N_{\mathrm{CCN}, \mathrm{S}}$}

With the derived hygroscopicity for low volatility particles $\left(\kappa_{\mathrm{LV}} \approx 0.01\right)$ and the $\mathrm{CCN}$ measurement results we infer a proxy for the effective average hygroscopicity of the total ensemble of aerosol particles, including internally mixed CCNactive particles as well as externally mixed weakly $\mathrm{CCN}$ active particles $\left(\kappa_{\mathrm{t}}\right)$ as follows:

$\kappa_{\mathrm{t}, \mathrm{p}}(\mathrm{CCN})=\kappa_{\mathrm{a}} \cdot \mathrm{MAF}_{\mathrm{m}}+\kappa_{\mathrm{LV}} \cdot\left(1-\mathrm{MAF}_{\mathrm{m}}\right)$

in which $\kappa_{\mathrm{a}}$ is the observed effective hygroscopicity of CCNactive particles and $\mathrm{MAF}_{\mathrm{m}}$ the measured number fraction of $\mathrm{CCN}$-active particles at $270 \mathrm{~nm}$.

In Fig. 9a, $\kappa_{\mathrm{t}, \mathrm{p}}$ is plotted versus the observed $\kappa_{\mathrm{t}}$. The two variables exhibited a very good correlation $\left(R^{2}=0.94\right)$, whereby $\kappa_{\mathrm{t}}$ was slightly over-predicted for small values and slightly under-predicted for large values. This plot shows that $\kappa_{\mathrm{t}, \mathrm{p}}$ can be successfully derived from knowledge of the effective hygroscopicity of CCN-active $\left(\kappa_{\mathrm{a}}\right)$ and weakly $\mathrm{CCN}$-active particles $\left(\kappa_{\mathrm{LV}}\right)$ on the assumption that $1-\mathrm{MAF}_{\mathrm{m}}$ comprises the fraction of $\mathrm{CCN}$-inactive particles at a certain supersaturation. It confirms that $\kappa_{\mathrm{t}}$ is indeed a suitable proxy for the effective hygroscopicity of an external mixture of $\mathrm{CCN}$-active and weakly $\mathrm{CCN}$-active particles (see Rose et al., 2010b).

Assuming that the fraction of $\mathrm{CCN}$-inactive particles at a certain supersaturation equals the fraction of LV-particles $\left(1-\mathrm{MAF}_{\mathrm{m}} \approx \phi_{\mathrm{LV}}\right)$, we infer the $\kappa_{\mathrm{t}, \mathrm{p}}$ value using the VTDMA measurement results as follows:

$$
\begin{aligned}
\kappa_{\mathrm{t}, \mathrm{p}}(\mathrm{VT}) & =\kappa_{\mathrm{a}} \cdot\left(1-\phi_{\mathrm{LV}, \mathrm{D}_{\mathrm{a}}}\right)+\kappa_{\mathrm{LV}} \cdot \phi_{\mathrm{LV}, \mathrm{D}_{\mathrm{a}}} \\
& =\kappa_{\mathrm{a}}-\phi_{\mathrm{LV}, \mathrm{D}_{\mathrm{a}}}\left(\kappa_{\mathrm{a}}-\kappa_{\mathrm{LV}}\right)
\end{aligned}
$$

in which $\kappa_{\mathrm{a}}$ is the observed effective hygroscopicity of internally mixed CCN- active particles and $\phi_{\mathrm{LV}, \mathrm{D}_{\mathrm{a}}}$ the number fraction of LV-particles with $D_{\mathrm{VT}}$ close to the activation diameter $D_{\mathrm{a}}$.

In Fig. 9b, $\kappa_{\mathrm{t}, \mathrm{p}}$ calculated from Eq. (4) is plotted versus the observed $\kappa_{\mathrm{t}}$. The two variables exhibited still a very good correlation $\left(R^{2}=0.89\right)$, with $\kappa_{\mathrm{t}}$ being slightly over-predicted for small values and slightly under-predicted for large values. It shows that $\kappa_{\mathrm{t}, \mathrm{p}}$ can be successfully derived from knowledge of the effective hygroscopicity of the internally mixed CCNactive particles $\left(\kappa_{\mathrm{a}}\right)$ and of the externally mixed low volatility particles $\left(\kappa_{\mathrm{LV}}\right)$, as well as the mixing state. Note that the relative deviation between the predicted and the measured $\kappa_{\mathrm{t}}$ became a little larger when MAF decreased but not when $\phi_{\mathrm{LV}}$ increased.

In the next step, we predict $\kappa_{\mathrm{t}}$ only from information about the size-resolved chemical composition of the particles and the mixing state, i.e., we use the AMS and VTDMA measurement results but no CCN data. $\kappa_{\mathrm{t}, \mathrm{p}}$ is then calculated by: 
Table 4. Arithmetic means of the observed $\kappa_{\mathrm{t}}$ and $N_{\mathrm{CCN}, \mathrm{S}}$ values, and characteristic deviations between predicted values $\left(\kappa_{\mathrm{t}, \mathrm{p}}\right.$ and $\left.N_{\mathrm{CCN}, \mathrm{S}, \mathrm{p}}\right)$ and those observed (relative bias and total relative deviation, including systematic and statistical errors) for the entire campaign. $n_{\kappa}$ and $n_{\mathrm{N}}$ are the number of data points that are contained in the averages of $\kappa_{\mathrm{t}, \mathrm{p}}$ and $N_{\mathrm{CCN}, \mathrm{S}, \mathrm{p}}$, respectively. Note that comparable values from Table 3 might differ from the ones in this table due to different averaging periods.

\begin{tabular}{|c|c|c|c|c|c|c|c|c|c|c|}
\hline$[\%]$ & $\kappa_{\mathrm{t}}$ & $\begin{array}{r}\kappa_{\mathrm{t}, \mathrm{p}}(\mathrm{VT}, \\
\text { rel. bias } \\
{[\%]}\end{array}$ & $\begin{array}{r}\text {, Eq. (5) } \\
\text { rel. dev. } \\
{[\%]}\end{array}$ & $n_{\kappa}$ & $\begin{array}{l}N_{\mathrm{CCN}, \mathrm{S}} \\
{\left[\mathrm{cm}^{-3}\right]}\end{array}$ & $\begin{array}{c}N_{\mathrm{CCN}, \mathrm{S}, \mathrm{p}} \\
\text { rel. bias } \\
{[\%]}\end{array}$ & $\begin{array}{l}\text { T,AMS) } \\
\text { rel. dev. } \\
{[\%]}\end{array}$ & $\begin{array}{c}N_{\mathrm{CCN}, \mathrm{S}, \mathrm{f}} \\
\text { rel. bias } \\
{[\%]}\end{array}$ & $\begin{array}{r}\text { th } \kappa=0.3 \\
\text { rel. dev. } \\
{[\%]}\end{array}$ & $n_{\mathrm{N}}$ \\
\hline 0.068 & 0.32 & +1.0 & 14.6 & 155 & 1214 & +10.5 & 15.2 & +8.0 & 18.2 & 116 \\
\hline 0.27 & 0.33 & -1.4 & 21.5 & 150 & 7069 & +7.8 & 11.3 & +10.3 & 19.3 & 114 \\
\hline 0.47 & 0.27 & +10.4 & 26.3 & 104 & 9268 & +10.2 & 12.4 & +15.7 & 16.7 & 90 \\
\hline all & 0.31 & +2.5 & 20.1 & 409 & & +9.4 & 13.0 & +11.0 & 18.2 & 320 \\
\hline
\end{tabular}

$$
\begin{aligned}
\kappa_{\mathrm{t}, \mathrm{p}}(\mathrm{VT}, \mathrm{AMS}) & =\kappa_{\mathrm{a}, \mathrm{p}} \cdot\left(1-\phi_{\mathrm{LV}, \mathrm{D}_{\mathrm{a}}}\right)+\kappa_{\mathrm{LV}} \cdot \phi_{\mathrm{LV}, \mathrm{D}_{\mathrm{a}}} \\
& =\kappa_{\mathrm{a}, \mathrm{p}}-\phi_{\mathrm{LV}, \mathrm{D}_{\mathrm{a}}}\left(\kappa_{\mathrm{a}, \mathrm{p}}-\kappa_{\mathrm{LV}}\right)
\end{aligned}
$$

in which $\kappa_{\mathrm{a}, \mathrm{p}}$ is calculated from $f_{\text {org }}$ and $f_{\text {inorg }}$ by Eq. (1).

Figure 9c shows $\kappa_{\mathrm{t}, \mathrm{p}}$ calculated with Eq. (5) plotted versus the observed $\kappa_{\mathrm{t}}$. It can be seen that the prediction of $\kappa_{\mathrm{t}}$ only from data of the chemical composition and mixing state was less successful since only a moderate correlation $\left(R^{2}=0.52\right)$ could be found. In the range between $\kappa=0.25$ to 0.55 , where $\sim 70 \%$ of the data points lay, the predicted values deviated from the observed ones on average by less than 20\%. For smaller values, $\kappa_{\mathrm{t}, \mathrm{p}}$ was generally larger than the observed $\kappa_{\mathrm{t}}$ (by up to $100 \%$ and more), whereas for larger values it was mainly smaller (by up to a few tens of percent). Table 4 shows that the deviations between $\kappa_{\mathrm{t}, \mathrm{p}}$ and the observed $\kappa_{\mathrm{t}}$ increased with supersaturation. However, the deviations were independent of MAF (not shown here).

Similar to the calculation in Sect. 3.1.2, $N_{\mathrm{CCN}, \mathrm{S}, \mathrm{p}}$ was determined from the predicted $\kappa_{\mathrm{t}}$ values. In spite of the low correlation of predicted versus observed $\kappa$ values, the relative deviations between $N_{\mathrm{CCN} \text {, S }}$ predicted on the basis of $\kappa_{\mathrm{t}, \mathrm{p}}(\mathrm{VT}, \mathrm{AMS})$ and the observed values of $N_{\mathrm{CCN}, \mathrm{S}}$ were on average $13 \%$ with a generally positive bias (Table 4, Fig. 10). In contrast to the prediction using $\kappa_{\mathrm{a}, \mathrm{p}}$ (Eq. (1), Table 3), the deviations did not increase for the smaller supersaturations.

When calculating $N_{\mathrm{CCN}, \mathrm{S}, \mathrm{p}}$ for the same data set using a constant $\kappa$ of 0.3 , the relative deviations between the predicted and observed values of $N_{\mathrm{CCN}, \mathrm{S}}$ were larger ( $\sim 18 \%$ on average) than when calculated with $\kappa_{\mathrm{t}, \mathrm{p}}(\mathrm{VT}, \mathrm{AMS})$. This is in contrast to what was found in Sect. 3.1.2 (more accurate prediction of $N_{\mathrm{CCN}, \mathrm{S}}$ using a constant $\kappa_{\mathrm{t}}=0.3$ than using individual $\kappa_{\mathrm{a}, \mathrm{p}}$ ) and it confirms the findings of Rose et al. (2010a): $\kappa_{\mathrm{t}}$ is a better proxy for the prediction of $N_{\mathrm{CCN}, \mathrm{S}}$ than $\kappa_{\mathrm{a}}$, if the aerosol consists of a fraction of $\mathrm{CCN}$-active and a fraction of weakly $\mathrm{CCN}$-active particles with much lower hygroscopicity. Moreover, a constant average value of $\kappa=0.3$ is a good approximation, if no information on particle composition is available, but cannot account for the ob-

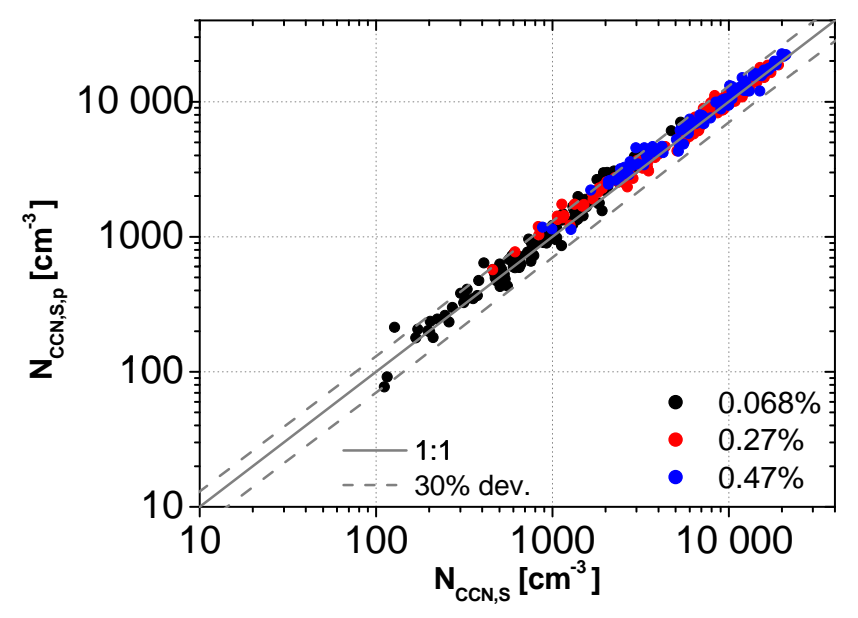

Fig. 10. Predicted CCN number concentrations $\left(N_{\mathrm{CCN}, \mathrm{S}, \mathrm{p}}\right)$ based on the measured $\mathrm{CN}$ size distribution and $\kappa_{\mathrm{t}, \mathrm{p}}(\mathrm{VT}, \mathrm{AMS})$ as calculated from Eq. (5) plotted against the observed CCN number concentrations $\left(N_{\mathrm{CCN}, \mathrm{S}}\right)$. The grey solid line is the $1: 1$ line, and the dashed lines indicate the band of $\pm 30 \%$ deviation of $N_{\mathrm{CCN}, \mathrm{S}, \mathrm{p}}$ from $N_{\mathrm{CCN}, \mathrm{S}}$.

served temporal variations in aerosol composition and CCN properties.

Figure 11 depicts the campaign average size distributions of $\kappa_{\mathrm{a}, \mathrm{p}}$ and $\kappa_{\mathrm{t}, \mathrm{p}}$ and the average measured $\kappa_{\mathrm{a}}$ and $\kappa_{\mathrm{t}}$ versus the activation diameter as observed at the four selected supersaturations. $\kappa_{\mathrm{a}, \mathrm{p}}$ was calculated by Eq. (1) using the average size distribution of the organic and inorganic mass fractions. $\kappa_{\mathrm{t}, \mathrm{p}}$ was calculated by Eq. (5) using the size distribution of $\kappa_{\mathrm{a}, \mathrm{p}}$ and $\phi_{\mathrm{LV}}$ calculated from the average $\mathrm{CN}$ and LV-particle size distribution. Below $70 \mathrm{~nm}, \kappa_{\mathrm{a}}$ and $\kappa_{\mathrm{t}}$ were almost the same for both the measured and the predicted values, but with increasing particle size, $\kappa_{\mathrm{a}}$ became significantly larger than $\kappa_{\mathrm{t}}$. This can be explained by the increasing fraction of LV-particles with particle size as indicated by the grey dashed line in Fig. 11, because $\kappa_{\mathrm{t}}$ is the combination of the hygroscopicity of the $\mathrm{CCN}$-active particles $\left(\kappa_{\mathrm{a}}\right)$ and the much lower hygroscopicity of the LV-particles $\left(\kappa_{\mathrm{LV}}\right)$. 


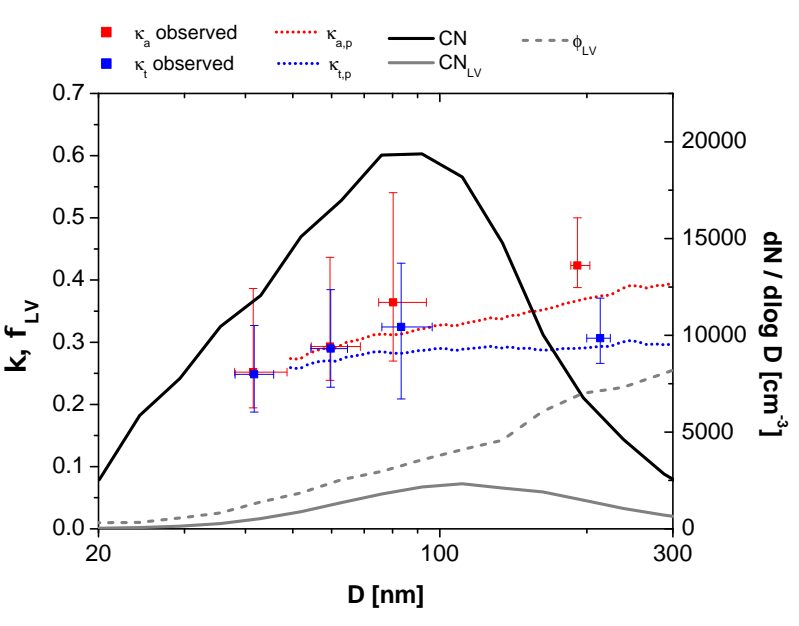

Fig. 11. Comparison of the predicted (red and blue lines, left axis) and measured (red and blue data points, left axis) hygroscopicity parameters. Supporting lines are the number size distribution of $\mathrm{CN}$ (solid black, right axis), of LV-particles (solid grey, right axis), and of the fraction of LV-particles (dashed grey, left axis) averaged over the campaign. Lines and data points are median values, and error bars indicate the interquartile ranges of the corresponding data points.

For $\kappa_{\mathrm{t}}$, the observed values were only slightly higher than the predicted ones, but for $\kappa_{\mathrm{a}}$ the measured values differed considerably for $D>70 \mathrm{~nm}$. As observed already in Fig. 4, $\kappa_{\mathrm{a}, \mathrm{p}}$ was significantly lower than $\kappa_{\mathrm{a}}$ for larger $\kappa$ values, which were typically observed for larger particle sizes ( $\sim 15 \%$ under-prediction for particles $\geq 70 \mathrm{~nm}$ ). Since the uncertainty of mass concentrations was relatively small at these sizes, this result suggests that the discrepancy between measured and predicted $\kappa_{\mathrm{a}}$ is not likely to be due to unreliable AMS data. It rather suggests that the effective hygroscopicity of the inorganic and/or organic fraction $\left(\kappa_{\text {inorg }}\right.$ and/or $\kappa_{\text {org }}$ ) is size-dependent (increased $\kappa_{\text {inorg }}$ and/or $\kappa_{\text {org }}$ with increasing particle size). It may also result from different and temporally varying molecular composition and hygroscopic properties of the organic fraction of the investigated aerosols.

\subsection{Diurnal cycles}

Figure 12 displays the statistical distributions of the diurnal cycles of selected parameters obtained from 30 days of $\mathrm{CCN}$, AMS, VTDMA, and optical measurements. The CCN derived parameters are plotted for higher and/or lower supersaturation corresponding to a smaller and larger particle size, respectively. The diurnal cycles of the $\kappa$ values are presented as normalized parameters. To normalize the data, each observed value was divided by its respective 24-hour average (arithmetic mean) on the day of measurement. Thus, a value of one indicates the daily average. The AMS derived mass concentrations and mass fractions are also shown for small and large sizes (integrated from $50-70 \mathrm{~nm}$ and $150-250 \mathrm{~nm}$, respectively).
In panels $\mathrm{a}$ and $\mathrm{b}$ the diurnal cycles of the effective hygroscopicity of the $\mathrm{CCN}$-active particles are shown. For the smaller particles measured at larger supersaturations (panel a), $\kappa_{\mathrm{a}}$ exhibited a clear minimum in the evening (20:00 to 22:00) and maximum values during day time, whereas for the larger particles measured at lower supersaturations (panel b) hardly any diurnal variation existed (less than $\pm 10 \%$ variation of the mean $\kappa_{\mathrm{a}}$ ).

For small particles, the mass concentrations of the inorganic and organic components measured by the AMS also exhibited pronounced cycles (panels c and e). The inorganic mass concentration was lowest during the night and in the morning, started increasing at noon and reached its maximum at 16:00 to $18: 00$ (maximum twice as high as minimum mean value). Afterwards it went slowly down before it reached its minimum level around midnight. The organic mass concentration had its minimum level also in the morning but increased more slowly than the inorganics and reached the maximum only around midnight, which may be due to enhanced condensation of semivolatile SOA. Due to the slightly shifted cycles for organics and inorganics the inorganic mass fraction (panel g) exhibited also a diurnal cycle. It had its minimum level around midnight and a twice as high maximum around noon. Since the variation of the inorganic mass fraction determines the variation of $\kappa_{\mathrm{a}}$, the two cycles were very similar (panel g vs. a).

For the larger particles, the inorganic and organic mass concentrations (panel d, f) also exhibited pronounced diurnal variations although they were a little smaller than for the small particles. The minimum was around noon, but in contrast to the small particles the concentrations increased almost in parallel to each other to a maximum level at around midnight. Therefore, the inorganic mass fraction (panel h) varied only a little during the day, which explains the small diurnal cycle of $\kappa_{\mathrm{a}}$ for the large particles (panel b).

Figure $12 \mathrm{k}$ shows $\sigma_{\mathrm{a}} / D_{\mathrm{a}}$, which is the normalized width of the CCN efficiency spectra (3 parameter CDF fit). It indicates the degree of particle heterogeneity and would ideally be zero for a fully homogeneous aerosol (Rose et al., 2010a). For small particles, the minimum values were reached around noon, while the maximum values at midnight were three times as high, which means that the particles were more homogeneously mixed during the day. For the larger particles, $\sigma_{\mathrm{a}} / D_{\mathrm{a}}$ exhibited no diurnal variation (not shown here).

The diurnal cycles of the parameters discussed above indicate that the small aerosol particles were mainly formed from gas phase precursors (secondary aerosol formation). Intense new particle formation and growth leading to similar diurnal cycles were recently reported for another measurement site in the vicinity of a Chinese mega-city (Beijing, Wiedensohler et al., 2009).

In Fig. $12 \mathrm{i}$ and $\mathrm{j}$, the diurnal cycles of the effective hygroscopicity of the total particle ensemble of particles, $\kappa_{\mathrm{t}}$, are plotted. They were more pronounced than for $\kappa_{\mathrm{a}}$ especially for the large particles because they reflect also the strong 

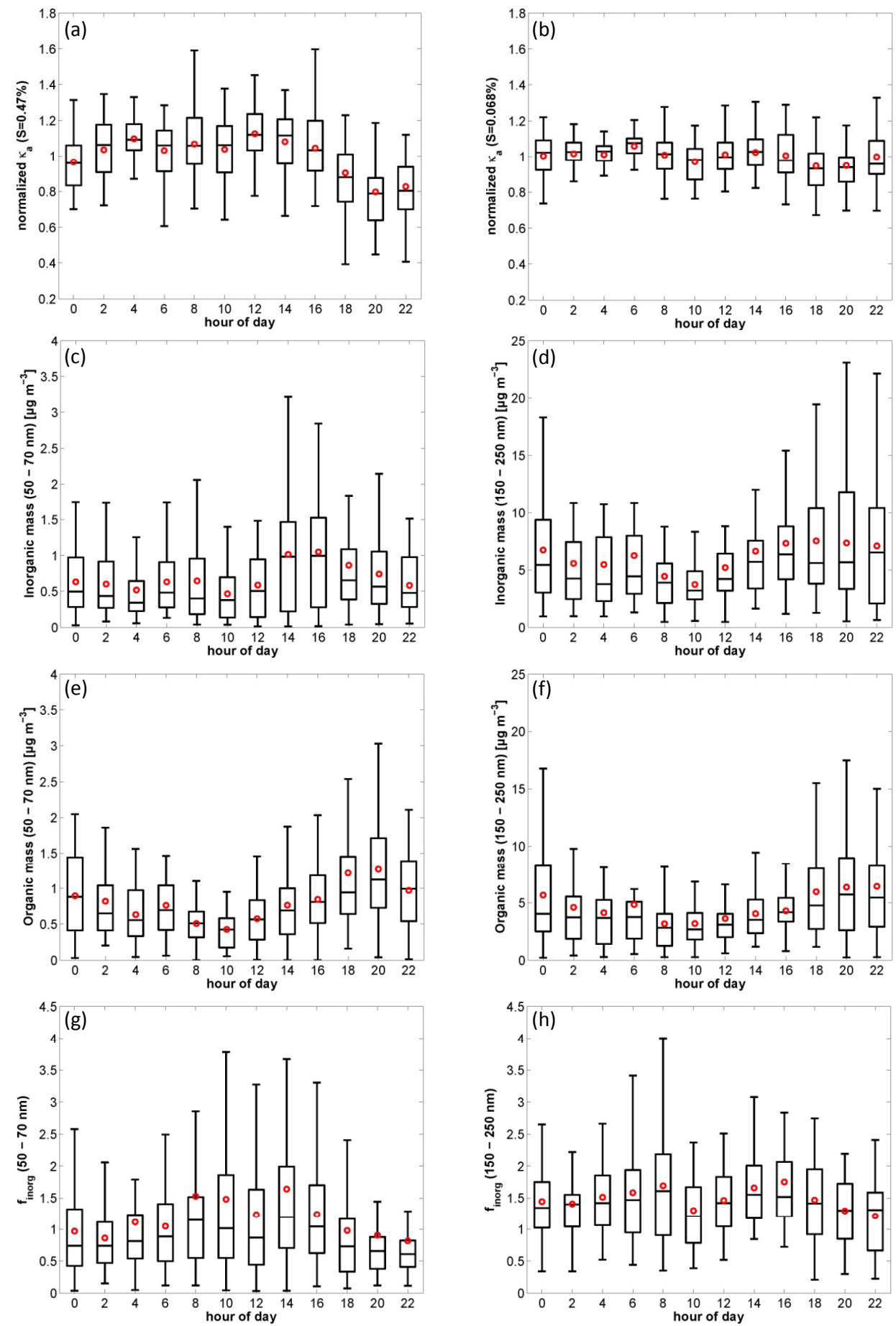

Fig. 12. Statistical distribution of diurnal cycles of several parameters obtained from CCN, AMS, VTDMA, and optical measurement results. The red dot is the mean value, the horizontal line in the box is the median, the limits of the boxes are the 25th and 75th percentile and the vertical lines extend to 5th and 95th percentiles. CCN derived parameters are plotted for higher (left panels) and/or lower (right panels) supersaturation corresponding to a smaller and larger particle size, respectively. The $\kappa$ values are normalized by dividing the observed value by the daily average of that parameter. Mass concentrations and mass fractions are integrated from 50 to $70 \mathrm{~nm}$ (left panels) and from 150 to $250 \mathrm{~nm}$ (right panels). 

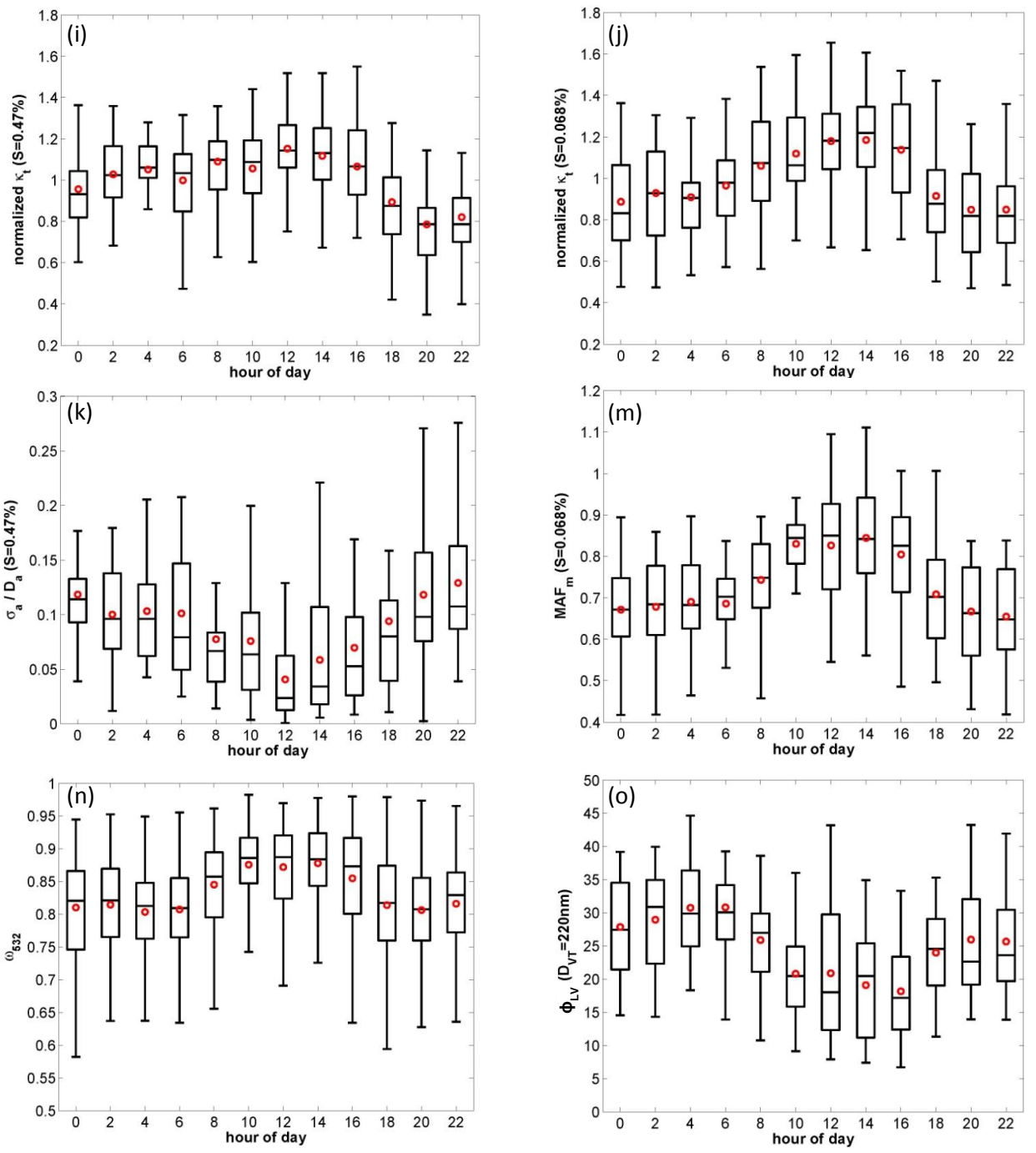

Fig. 12. Continued.

diurnal variations of the fraction of the weakly $\mathrm{CCN}$-active LV-particles.

The maximum activated fractions derived from the $\mathrm{CCN}$ efficiency spectra measured at the smallest supersaturation $\left(\mathrm{MAF}_{\mathrm{m}}\right.$, panel $\left.\mathrm{m}\right)$ exhibited the highest values $(\sim 0.8)$ between 12:00 to 18:00 and the lowest values $(\sim 0.65)$ around midnight. It indicates that there must have been more externally mixed weakly $\mathrm{CCN}$-active particles during night time.

The results of the volatility and optical measurements support these findings. The number fraction of LV-particles $\left(\phi_{\mathrm{LV}, 220}\right.$, panel o) was lowest between 12:00 to 18:00. The LV-particles reached their absolute maximum fraction between 02:00 and 08:00, which was a few hours after the minimum of $\mathrm{MAF}_{\mathrm{m}}$ and $\kappa_{\mathrm{t}}$. The single scattering albedo (panel $\mathrm{n}$ ) indicates higher proportions of light absorbing material (soot) during night $\left(\omega_{532} \approx 0.8\right)$ than during day time $\left(\omega_{532} \approx 0.9\right)$.

Most likely the diurnal cycles of the parameters shown in Fig. 12i-o were dominated by convective mixing during daytime leading to dilution and to a decrease of the soot fraction. After sunset, the formation of a stable nocturnal boundary layer in combination with the continued emission or advection of particles throughout the night led to an increase of the LV-particles (fresh soot). As mentioned also in Andreae et al. (2008) and Garland et al. (2008), truck traffic, dominated by high-emission diesel vehicles, increased sharply at night as a result of local traffic regulations. Since the measurement site was located in the upwind area of the mega-city Guangzhou, increased diesel emissions had to be expected and probably contributed to the evening increase in fresh soot at our site. 


\section{Summary and conclusions}

In this study, which is a companion to Rose et al. (2010a), we used data from AMS, VTDMA, and optical measurements to investigate and characterize the relationship between CCN activity, hygroscopicity, chemical composition, and mixing state of aerosol particles in mega-city air and biomass burning smoke.

Two different hygroscopicity parameters were derived from the $\mathrm{CCN}$ measurements. The parameter $\kappa_{\mathrm{a}}$ characterizes the average hygroscopicity of the internally mixed CCNactive particles whereas the parameter $\kappa_{\mathrm{t}}$ is an approximate measure (proxy) for the effective average hygroscopicity of the total ensemble of aerosol particles including internally mixed $\mathrm{CCN}$-active as well as externally mixed weakly CCNactive particles. Both of these parameters were consistent with AMS and VTDMA measurement data. The $\kappa_{\mathrm{a}}$ values increased with particle size from $\sim 0.25$ at $\sim 50 \mathrm{~nm}$ to $\sim 0.4$ at $\sim 200 \mathrm{~nm}$. The organic mass fraction $\left(f_{\text {org }}\right)$ was negatively correlated with $\kappa_{\mathrm{a}}$ and decreased with particle size. For the smallest particles $(\sim 50 \mathrm{~nm}), f_{\text {org }}$ was on average $60 \%$ (campaign median), but increased to almost 100\% during a biomass burning event (BBE). For particles $\geq 200 \mathrm{~nm}$, it remained nearly constant during the entire campaign at 40 $50 \%$. Moreover, the mass concentrations of all chemical components measured by the AMS were about twice as high during the BBE than during the rest of the campaign. The campaign average mass concentration over the investigated size range $(50-850 \mathrm{~nm})$ was $\sim 40 \mu \mathrm{g} \mathrm{m}^{-3}$.

Extrapolation of the linear correlation between $\kappa_{\mathrm{a}}$ and $f_{\text {org }}$ yielded the following $\kappa$ values for organic and inorganic particle components: $\kappa_{\text {org }} \approx 0.1$, which can be regarded as the effective hygroscopicity of secondary organic aerosol (SOA) and $\kappa_{\text {inorg }} \approx 0.6$, which is characteristic for ammonium sulfate and related salts. They were similar to those observed in other regions of the world (e.g., Gunthe et al., 2009; Dusek et al., 2010). Both the size dependence and the temporal variability of effective particle hygroscopicity could be parameterized as a function of AMS-based organic and inorganic mass fractions (Gunthe et al., 2009): $\kappa_{\mathrm{a}, \mathrm{p}}=\kappa_{\mathrm{org}} \cdot f_{\text {org }}+\kappa_{\text {inorg }} \cdot$ $f_{\text {inorg }}$. The $\mathrm{CCN}$ number concentrations $\left(N_{\mathrm{CCN}, \mathrm{S}}\right)$ predicted with $\kappa_{\mathrm{a}, \mathrm{p}}$ exhibited a substantial positive bias relative to the measurement results (up to $+34 \%$ on average at $S=0.068 \%$ ). This confirms that AMS data are not sufficient for accurate predictions of $N_{\mathrm{CCN}, \mathrm{S}}$, if a significant fraction of externally mixed weakly $\mathrm{CCN}$-active particles is present as observed for this data set.

As already described in Rose et al. (2010a), the CCN efficiency spectra observed at low $S(\leq 0.27 \%)$ exhibited maximum activated fractions (MAF) well below one, indicating substantial portions of externally mixed weakly CCNactive particles with very low hygroscopicity. The VTDMA measurement results and complementary aerosol optical data suggest that those particles were externally mixed soot particles with low volatility (LV-particles) freshly emitted from local and regional combustion sources. By combining CCN and VTDMA data we obtained an estimate of $\kappa_{\mathrm{LV}} \approx 0.01$ for the effective average hygroscopicity of the LV-particles. Based on AMS and VTDMA data we could also calculate a proxy for the effective average hygroscopicity of the total particle ensemble: $\kappa_{\mathrm{t}, \mathrm{p}}=\kappa_{\mathrm{a}, \mathrm{p}}-\phi_{\mathrm{LV}} \cdot\left(\kappa_{\mathrm{a}, \mathrm{p}}-\kappa_{\mathrm{LV}}\right)$. The prediction of $N_{\mathrm{CCN}, \mathrm{S}}$ with $\kappa_{\mathrm{t}, \mathrm{p}}(\sim 10 \%$ average deviation) was much better than with $\kappa_{\mathrm{a}, \mathrm{p}}(\sim 20 \%$ average deviation). These findings confirm that information on the mixing state is essential for highly accurate $\mathrm{CCN}$ predictions in polluted environments with strong combustion sources.

Throughout the measurement campaign, the LV-particle fractions and the deviations between $\kappa_{\mathrm{t}, \mathrm{p}}$ and $\kappa_{\mathrm{a}, \mathrm{p}}$ were enhanced during nighttime. These diurnal cycles are consistent with aerosol optical data and can be attributed to boundary layer mixing effects and enhanced nighttime emissions from combustion sources (Garland et al., 2008).

The campaign average value of $\kappa_{\mathrm{t}} \approx 0.3$ was the same as observed and estimated for other continental regions (Rose et al., 2010a; Andreae and Rosenfeld, 2008). In accordance with recent simulations of the global distribution of $\kappa$ with an atmospheric chemistry model (Pringle et al., 2010), this value can be regarded as an approximate global average effective hygroscopicity parameter of $\mathrm{CCN}$ in continental air.

The prediction of $N_{\mathrm{CCN}, \mathrm{S}}$ assuming constant $\kappa=0.3$ ( $\sim 18 \%$ average deviation) was worse than the prediction using variable $\kappa_{\mathrm{t}, \mathrm{p}}$ values based on AMS and VTDMA data but slightly better than the prediction using variable $\kappa_{\mathrm{a}, \mathrm{p}}$ values based on AMS data only. These results re-confirm that on a global and climate modeling scale $\kappa=0.3$ is suitable as a first-order approximation for the effective hygroscopicity and $\mathrm{CCN}$ activity of continental aerosols, although it cannot account for the regional and temporal variations in aerosol composition and mixing state.

Depending on the required and applicable level of detail, the information and parameterizations presented in this study should enable efficient description of the $\mathrm{CCN}$ activity of atmospheric aerosols in detailed process models as well as in large-scale atmospheric and climate models.

Acknowledgements. The PRIDE-PRD2006 campaign was sponsored by the China National Basic Research and Development Program (2002CB410801 and 2002CB211605). This study was supported by the Max Planck Society (MPG), the Leibniz Institute for Tropospheric Research (IfT), the University of Tokyo (UT), and Peking University (PKU). Thanks to all team members for support during the campaign and fruitful discussions afterwards.

The service charges for this open access publication have been covered by the Max Planck Society.

Edited by: A. Hofzumahaus 


\section{References}

Andreae, M. O.: Correlation between cloud condensation nuclei concentration and aerosol optical thickness in remote and polluted regions, Atmos. Chem. Phys., 9, 543-556, doi:10.5194/acp-9-543-2009, 2009.

Andreae, M. O. and Gelencsér, A.: Black carbon or brown carbon? The nature of light-absorbing carbonaceous aerosols, Atmos. Chem. Phys., 6, 3131-3148, doi:10.5194/acp-6-3131-2006, 2006.

Andreae, M. O. and Rosenfeld, D.: Aerosol-cloud-precipitation interactions. Part 1. The nature and sources of cloud-active aerosols, Earth Sci. Rev., 89, 13-41, 2008.

Andreae, M. O., Schmid, O., Yang, H., Yu, J., Zeng, L., and Zhang, Y.: Optical properties and chemical composition of the atmospheric aerosol in urban Guangzhou, China, Atmos. Environ., 42, 6335-6350, doi:10.1016/j.atmosenv.2008.01.030, 2008.

Anttila, T.: Sensitivity of cloud droplet formation to the numerical treatment of the particle mixing state, J. Geophys. Res., 115, D21205, doi:10.1029/2010JD013995, 2010.

Birmili, W., Stratmann, F., and Wiedensohler, A.: Design of a DMA-based size spectrometer for a large particle size range and stable operation, J. Aerosol Sci., 30, 4, 549-553, 1999.

Bougiatioti, A., Fountoukis, C., Kalivitis, N., Pandis, S. N., Nenes, A., and Mihalopoulos, N.: Cloud condensation nuclei measurements in the marine boundary layer of the Eastern Mediterranean: CCN closure and droplet growth kinetics, Atmos. Chem. Phys., 9, 7053-7066, doi:10.5194/acp-9-7053-2009, 2009.

Broekhuizen, K., Chang, R.-W., Leaitch, W. R., Li, S.-M., and Abbatt, J. P. D.: Closure between measured and modeled cloud condensation nuclei (CCN) using size-resolved aerosol compositions in downtown Toronto, Atmos. Chem. Phys., 6, 2513-2524, doi:10.5194/acp-6-2513-2006, 2006.

Burtscher, H., Baltensperger, U., Bukowiecki, N., Cohn, P., Hüglin, C., Mohr, M., Matter, U., Nyeki, S., Schmatloch, V., and Streit, N.: Separation of volatile and non-volatile aerosol fractions by thermodesorption: instrumental development and applications, J. Aerosol Sci., 32, 427-442, 2001.

Chang, R. Y.-W., Slowik, J. G., Shantz, N. C., Vlasenko, A., Liggio, J., Sjostedt, S. J., Leaitch, W. R., and Abbatt, J. P. D.: The hygroscopicity parameter $(\kappa)$ of ambient organic aerosol at a field site subject to biogenic and anthropogenic influences: relationship to degree of aerosol oxidation, Atmos. Chem. Phys., 10, 50475064, doi:10.5194/acp-10-5047-2010, 2010.

Cheng, Y. F., Eichler, H., Wiedensohler, A., Heintzenberg, J., Zhang, Y. H., Hu, M., Herrmann, H., Zeng, L. M., Liu, S., Gnauk, T., Brüggemann, E., and He, L. Y.: Mixing state of elemental carbon and non-light-absorbing aerosol components derived from in situ particle optical properties at Xinken in Pearl River Delta of China, J. Geophys. Res., 111, D20204, doi:10.1029/2005JD006929, 2006.

Cheng, Y. F., Berghof, M., Garland, R. M., Wiedensohler, A., Wehner, B., Müller, T., Su, H., Zhang, Y. H., Achtert, P., Nowak, A., Pöschl, U., Zhu, T., Hu, M., and Zeng, L. M.: Influence of soot mixing state on aerosol light absorption and single scattering albedo during air mass aging at a polluted regional site in northeastern China, J. Geophys. Res., 114, D00G10, doi:10.1029/2008JD010883, 2009.

Cubison, M. J., Ervens, B., Feingold, G., Docherty, K. S., Ulbrich, I. M., Shields, L., Prather, K., Hering, S., and Jimenez, J. L.:
The influence of chemical composition and mixing state of Los Angeles urban aerosol on CCN number and cloud properties, Atmos. Chem. Phys., 8, 5649-5667, doi:10.5194/acp-8-5649-2008, 2008.

DeCarlo, P. F., Slowik, J. G., Worsnop, D. R., Davidovits, P., and Jimenez, J. L.: Particle Morphology and Density Characterization by Combined Mobility and Aerodynamic Diameter Measurements. Part 1: Theory, Aerosol Sci. Technol., 38, 11851205, 2004.

Dusek, U., Frank, G. P., Hildebrandt, L., Curtius, J., Schneider, J., Walter, S., Chand, D., Drewnick, F., Hings, S., Jung, D., Borrmann, S., and Andreae, M. O.: Size matters more than chemistry for cloud nucleating ability of aerosol particles, Science, 312, 1375-1378, 2006.

Dusek, U., Frank, G. P., Curtius, J., Drewnick, F., Schneider, J., Kürten, A., Rose, D., Andreae, M. O., Borrmann, S., and Pöschl, U.: Enhanced organic mass fraction and decreased hygroscopicity of cloud condensation nuclei (CCN) during new particle formation events, Geophys. Res. Lett., 37, L03804, doi:10.1029/2009GL040930, 2010.

Ervens, B., Cubison, M., Andrews, E., Feingold, G., Ogren, J., Jimenez, J., DeCarlo, P., and Nenes, A.: Prediction of cloud condensation nucleus number concentration using measurements of aerosol size distributions and composition and light scattering enhancement due to humidity, J. Geophys. Res., 112, doi:10.1029/2006JD007426, 2007.

Ervens, B., Cubison, M. J., Andrews, E., Feingold, G., Ogren, J. A., Jimenez, J. L., Quinn, P. K., Bates, T. S., Wang, J., Zhang, Q., Coe, H., Flynn, M., and Allan, J. D.: CCN predictions using simplified assumptions of organic aerosol composition and mixing state: a synthesis from six different locations, Atmos. Chem. Phys., 10, 4795-4807, doi:10.5194/acp-10-4795-2010, 2010.

Frank, G. P., Dusek, U., and Andreae, M. O.: Technical note: A method for measuring size-resolved CCN in the atmosphere, Atmos. Chem. Phys. Discuss., 6, 4879-4895, doi:10.5194/acp-86365-2006, 2006.

Frey, A., Rose, D., Wehner, B., Müller, T., Cheng, Y., Wiedensohler, A., and Virkkula, A.: Application of the Volatility-TDMA Technique to Determine the Number Size Distribution and Mass Concentration of Less Volatile Particles, Aerosol Sci. Technol., 42, 817-828, 2008.

Garland, R. M., Yang, H., Schmid, O., Rose, D., Nowak, A., Achtert, P., Wiedensohler, A., Takegawa, N., Kita, K., Miyazaki, Y., Kondo, Y., Hu, M., Shao, M., Zeng, L. M., Zhang, Y. H., Andreae, M. O., and Pöschl, U.: Aerosol optical properties in a rural environment near the mega-city Guangzhou, China: implications for regional air pollution, radiative forcing and remote sensing, Atmos. Chem. Phys., 8, 5161-5186, doi:10.5194/acp-85161-2008, 2008.

Gunthe, S. S., King, S. M., Rose, D., Chen, Q., Roldin, P., Farmer, D. K., Jimenez, J. L., Artaxo, P., Andreae, M. O., Martin, S. T., and Pöschl, U.: Cloud condensation nuclei in pristine tropical rainforest air of Amazonia: size-resolved measurements and modeling of atmospheric aerosol composition and CCN activity, Atmos. Chem. Phys., 9, 7551-7575, doi:10.5194/acp-9-75512009, 2009.

Heintzenberg, J. and Charlson, R. J.: Clouds in the Perturbed Climate System: Their Relationship to Energy Balance, Atmospheric Dynamics, and Precipitation, Strüngmann Forum Report, 
vol. 2, MIT Press, Cambridge, MA, USA, 2009.

Huang, Y., Chameides, W. L., and Dickinson, R. E.: Direct and indirect effects of anthropogenic aerosols on regional precipitation over east Asia, J. Geophys. Res., 112, D03212, doi:10.1029/2006JD007114, 2007.

Hudson, J. G.: Variability of the relationship between particle size and cloud-nucleating ability, Geophys. Res. Lett., 34, L08801, doi:10.1029/2006GL028850, 2007.

Hudson, J. G. and Yum, S. S.: Cloud condensation nuclei spectra and polluted and clean clouds over the Indian Ocean, J. Geophys. Res., 107(D19), 8022, doi:10.1029/2001JD000829, 2002.

IPCC: Climate Change 2007: The Physical Science Basis. Contribution of Working Group I to the Fourth Assessment Report of the Intergovernmental Panel on Climate Change, p. 996, Cambridge University Press, Cambridge and New York, 2007.

Jayne, J. T., Leard, D. C., Zhang, X. F., Davidovits, P., Smith, K. A., Kolb, C. E., and Worsnop, D. R.: Development of an aerosol mass spectrometer for size and composition analysis of submicron particles, Aerosol Sci. Technol., 33, 49-70, 2000.

Jurányi, Z., Gysel, M., Weingartner, E., DeCarlo, P. F., Kammermann, L., and Baltensperger, U.: Measured and modelled cloud condensation nuclei number concentration at the high alpine site Jungfraujoch, Atmos. Chem. Phys., 10, 7891-7906, doi:10.5194/acp-10-7891-2010, 2010.

King, S. M., Rosenøern, T., Shilling, J. E., Chen, Q., and Martin, S. T.: Increased cloud activation potential of secondary organic aerosol for atmospheric mass loadings, Atmos. Chem. Phys., 9, 2959-2971, doi:10.5194/acp-9-2959-2009, 2009.

King, S. M., Rosenøern, T., Shilling, J. E., Chen, Q., Wang, Z., Biskos, G., McKinney, K. A., Pöschl, U., and Martin, S. T.: Cloud droplet activation of mixed organic-sulfate particles produced by the photooxidation of isoprene, Atmos. Chem. Phys., 10, 3953-3964, doi:10.5194/acp-10-3953-2010, 2010.

Kondo, Y., Komazaki, Y., Miyazaki, Y., Moteki, N., Takegawa, N., Kodama, D., Deguchi, S., Nogami, M., Fukuda, M., and Miyakawa, T.: Temporal variations of elemental carbon in Tokyo, J. Geophys. Res, 111, D12205, doi:10.1029/2005JD006257, 2006.

Kreidenweis, S. M., Petters, M. D., and DeMott, P. J.: Singleparameter estimates of aerosol water content, Environ. Res. Lett., 3, 035002, doi:10.1088/1748-9326/3/3/035002, 2008.

Kreidenweis, S. M., Petters, M. D., and Chuang, P. Y.: Cloud particle precursors, in: Clouds in the Perturbed Climate System: Their Relationship to Energy Balance, Atmospheric Dynamics, and Precipitation, Strüngmann Forum Report, vol. 2, edited by: Heintzenberg, J. and Charlson, R. J., MIT Press, Cambridge, MA, USA, 2009.

Kuwata, M. and Kondo, Y.: Dependence of size-resolved $\mathrm{CCN}$ spectra on the mixing state of nonvolatile cores observed in Tokyo, J. Geophys. Res., 113, D19202, doi:10.1029/2007JD009761, 2008.

Kuwata, M., Kondo, Y., Mochida, M., Takegawa, N., and Kawamura, K.: Dependence of CCN activity of less volatile particles on the amount of coating observed in Tokyo, J. Geophys. Res., 112, D11207, doi:10.1029/2006JD007758, 2007.

Kuwata, M., Kondo, Y., Miyazaki, Y., Komazaki, Y., Kim, J. H., Yum, S. S., Tanimoto, H., and Matsueda, H.: Cloud condensation nuclei activity at Jeju Island, Korea in spring 2005, Atmos. Chem. Phys., 8, 2933-2948, doi:10.5194/acp-8-2933-2008,
2008.

Lance, S., Medina, J., Smith, J. N., and Nenes, A.: Mapping the Operation of the DMT Continuous Flow CCN Counter, Aerosol Sci. Technol., 40, 242-254, 2006.

Lance, S., Nenes, A., Mazzoleni, C., Dubey, M. K., Gates, H., Varutbangkul, V., Rissman, T. A., Murphy, S. M., Sorooshian, A., Flagan, R. C., Seinfeld, J. H., Feingold, G., and Jonsson, H. H.: Cloud condensation nuclei activity, closure, and droplet growth kinetics of Houston aerosol during the Gulf of Mexico Atmospheric Composition and Climate Study (GoMACCS), J. Geophys. Res., 114, D00F15, doi:10.1029/2008JD011699, 2009.

Lohmann, U. and Feichter, J.: Global indirect aerosol effects: a review, Atmos. Chem. Phys., 5, 715-737, doi:10.5194/acp-5-7152005, 2005.

Medina, J., Nenes, A., Sotiropoulou, R.-E. P., Cottrell, L. D., Ziemba, L. D., Beckman, P. J., and Griffin, R. J.: Cloud condensation nuclei closure during the International Consortium for Atmospheric Research on Transport and Transformation 2004 campaign: Effects of size-resolved composition, J. Geophys. Res., 112, D10S31, doi:10.1029/2006JD007588, 2007.

Mikhailov, E., Vlasenko, S., Martin, S. T., Koop, T., and Pöschl, U.: Amorphous and crystalline aerosol particles interacting with water vapor: conceptual framework and experimental evidence for restructuring, phase transitions and kinetic limitations, Atmos. Chem. Phys., 9, 9491-9522, doi:10.5194/acp-9-9491-2009, 2009.

Petters, M. D. and Kreidenweis, S. M.: A single parameter representation of hygroscopic growth and cloud condensation nucleus activity, Atmos. Chem. Phys., 7, 19611971, doi:10.5194/acp-71961-2007, 2007.

Philippin, S., Wiedensohler, A., and Stratmann, F.: Measurements of non-volatile fractions of pollution aerosols with an eight-tube volatility tandem differential mobility analyzer (VTDMA-8), J. Aerosol Sci., 35, 185-203, doi:10.1016/j.jaerosci.2003.07.004, 2004.

Pöschl, U.: Atmospheric aerosols: composition, transformation, climate and health effects, Angewandte Chemie International Edition, 44, 7520-7540, 2005.

Pöschl, U.: Gasparticle interactions of tropospheric aerosols: Kinetic and thermodynamic perspectives of multiphase chemical reactions, amorphous organic substances, and the activation of cloud condensation nuclei, Atmos. Res., doi:10.1016/j.atmosres.2010.12.018, in press, 2011.

Pöschl, U., Rose, D., and Andreae, M. O.: Climatologies of cloudrelated aerosols - Part 2: Particle hygroscopicity and cloud condensation nucleus activity, in: Clouds in the Perturbed Climate System: Their Relationship to Energy Balance, Atmospheric Dynamics, and Precipitation, Strüngmann Forum Report, vol. 2, edited by: Heintzenberg, J. and Charlson, R. J., MIT Press, Cambridge, MA, USA, 57-72, 2009.

Pringle, K. J., Tost, H., Pozzer, A., Pöschl, U., and Lelieveld, J.: Global distribution of the effective aerosol hygroscopicity parameter for CCN activation, Atmos. Chem. Phys., 10, 52415255, doi:10.5194/acp-10-5241-2010, 2010.

Pruppacher, H. R. and Klett, J. D.: Microphysics of clouds and precipitation, Kluwer Academic Publishers, Dordrecht, The Netherlands, 1997.

Roberts, G., Artaxo, P., Zhou, J., Swietlicki, E., and Andreae, 
M. O.: Sensitivity of CCN spectra on chemical and physical properties of aerosol: A case study from the Amazon Basin, J. Geophys. Res., 107, 8070, doi:10.1029/2001JD000583, 2002.

Roberts, G., Mauger, G., Hadley, O., and Ramanathan, V.: North American and Asian aerosols over the eastern Pacific Ocean and their role in regulating cloud condensation nuclei, J. Geophys. Res., 111, D13205, doi:10.1029/2005JD006661, 2006.

Roberts, G. C. and Nenes, A.: A Continuous-Flow Streamwise Thermal-Gradient CCN Chamber for Atmospheric Measurements, Aerosol Sci. Technol., 39, 206-221, 2005.

Roberts, G. C., Andreae, M. O., Zhou, J., and Artaxo, P.: Cloud condensation nuclei in the Amazon Basin: "Marine" conditions over a continent?, Geophys. Res. Lett., 28, 2807-2810, 2001.

Rose, D., Wehner, B., Ketzel, M., Engler, C., Voigtländer, J., Tuch, T., and Wiedensohler, A.: Atmospheric number size distributions of soot particles and estimation of emission factors, Atmos. Chem. Phys., 6, 1021-1031, doi:10.5194/acp-6-1021-2006, 2006.

Rose, D., Gunthe, S. S., Mikhailov, E., Frank, G. P., Dusek, U., Andreae, M. O., and Pöschl, U.: Calibration and measurement of a continuous-flow cloud condensation nuclei counter (DMTCCNC): CCN activation of ammonium sulfate and sodium chloride aerosol particles in theory and experiment, Atmos. Chem. Phys., 8, 1153-1179, doi:10.5194/acp-8-1153-2008, 2008.

Rose, D., Nowak, A., Achtert, P., Wiedensohler, A., Hu, M., Shao, M., Zhang, Y., Andreae, M. O., and Pöschl, U.: Cloud condensation nuclei in polluted air and biomass burning smoke near the mega-city Guangzhou, China - Part 1: Size-resolved measurements and implications for the modeling of aerosol particle hygroscopicity and CCN activity, Atmos. Chem. Phys., 10, 33653383, doi:10.5194/acp-10-3365-2010, 2010a.

Rose, D., Nowak, A., Achtert, P., Wiedensohler, A., Hu, M., Shao, M., Zhang, Y., Andreae, M. O., and Pöschl, U.: Interactive comment on "Cloud condensation nuclei in polluted air and biomass burning smoke near the mega-city Guangzhou, China - Part 1: Size-resolved measurements and implications for the modeling of aerosol particle hygroscopicity and CCN activity" by D. Rose et al., Atmos. Chem. Phys. Discuss., 8, S12597-S12599, doi:10.5194/acpd-8-S12597-2010, 2010 b.

Sadezky, A., Muckenhuber, H., Grothe, H., Niessner, R., and Pöschl, U.: Raman microspectroscopy of soot and related carbonaceous materials: spectral analysis and structural information, Carbon, 43, 1731-1742, 2005.

Seinfeld, J. H. and Pandis, S. N.: Atmospheric Chemistry and Physics: From Air Pollution to Climate Change, John Wiley and Sons, Inc., New York, USA, 2006.

Shantz, N. C., Chang, R. Y.-W., Slowik, J. G., Vlasenko, A., Abbatt, J. P. D., and Leaitch, W. R.: Slower CCN growth kinetics of anthropogenic aerosol compared to biogenic aerosol observed at a rural site, Atmos. Chem. Phys., 10, 299-312, doi:10.5194/acp10-299-2010, 2010.

Smith, M. H. and O'Dowd, C. D.: Observations of accumulation mode aerosol composition and soot carbon concentrations by means of a high-temperature volatility technique, J. Geophys. Res, 101, 19583-19591, 1996.

Stevens, B. and Feingold, G.: Untangling aerosol effects on clouds and precipitation in a buffered system, Nature, 461, 7264, doi:10.1038/nature08281, 2009.

Su, H., Rose, D., Cheng, Y. F., Gunthe, S. S., Massling, A., Stock,
M., Wiedensohler, A., Andreae, M. O., and Pöschl, U.: Hygroscopicity distribution concept for measurement data analysis and modeling of aerosol particle mixing state with regard to hygroscopic growth and CCN activation, Atmos. Chem. Phys., 10, 7489-7503, doi:10.5194/acp-10-7489-2010, 2010.

Takegawa, N., Miyakawa, T., Watanabe, M., Kondo, Y., Miyazaki, Y., Han, S., Zhao, Y., van Pinxteren, D., Brüggemann, E., Gnauk, T., Herrmann, H., Xiao, R., Deng, Z., Hu, M., Zhu, T., and Zhang, Y.: Performance of an Aerodyne Aerosol Mass Spectrometer (AMS) during Intensive Campaigns in China in the Summer of 2006, Aerosol Sci. Technol., 43, 189-204, doi:10.1080/02786820802582251, 2009.

Tuch, T. M., Haudek, A., Müller, T., Nowak, A., Wex, H., and Wiedensohler, A.: Design and performance of an automatic regenerating adsorption aerosol dryer for continuous operation at monitoring sites, Atmos. Meas. Tech., 2, 417-422, doi:10.5194/amt-2-417-2009, 2009.

Wang, J., Lee, Y.-N., Daum, P. H., Jayne, J., and Alexander, M. L.: Effects of aerosol organics on cloud condensation nucleus (CCN) concentration and first indirect aerosol effect, Atmos. Chem. Phys., 8, 6325-6339, doi:10.5194/acp-8-6325-2008, 2008.

Wang, J., Cubison, M. J., Aiken, A. C., Jimenez, J. L., and Collins, D. R.: The importance of aerosol mixing state and size-resolved composition on CCN concentration and the variation of the importance with atmospheric aging of aerosols, Atmos. Chem. Phys., 10, 7267-7283, doi:10.5194/acp-10-7267-2010, 2010.

Wehner, B., Berghof, M., Cheng, Y. F., Achtert, P., Birmili, W., Nowak, A., Wiedensohler, A., Garland, R. M., Pöschl, U., Hu, M., and Zhu, T.: Mixing state of nonvolatile aerosol particle fractions and comparison with light absorption in the polluted Beijing region, J. Geophys. Res., 114, D00G17, doi:10.1029/2008JD010923, 2009.

Wex, H., McFiggans, G., Henning, S., and Stratmann, F.: Influence of the external mixing state of atmospheric aerosol on derived CCN number concentrations, Geophys. Res. Lett., 37, L10805, doi:10.1029/2010GL043337, 2010.

Wiedensohler, A., Cheng, Y. F., Nowak, A., Wehner, B., Achtert, P., Berghof, M., Birmili, W., Wu, Z. J., Hu, M., Zhu, T., Takegawa, N., Kita, K., Kondo, Y., Lou, S. R., Hofzumahaus, A., Holland, F., Wahner, A., Gunthe, S. S., Rose, D., Su, H., and Pöschl, U.: Rapid aerosol particle growth and increase of cloud condensation nucleus activity by secondary aerosol formation and condensation: A case study for regional air pollution in northeastern China, J. Geophys. Res., 114, D00G08, doi:10.1029/2008JD010884, 2009.

Wiedensohler, A., Birmili, W., Nowak, A., Sonntag, A., Weinhold, K., Merkel, M., Wehner, B., Tuch, T., Pfeifer, S., Fiebig, M., Fjäraa, A. M., Asmi, E., Sellegri, K., Depuy, R., Venzac, H., Villani, P., Laj, P., Aalto, P., Ogren, J. A., Swietlicki, E., Roldin, P., Williams, P., Quincey, P., Hüglin, C., Fierz-Schmidhauser, R., Gysel, M., Weingartner, E., Riccobono, F., Santos, S., Grüning, C., Faloon, K., Beddows, D., Harrison, R. M., Monahan, C., Jennings, S. G., O’Dowd, C. D., Marinoni, A., Horn, H.-G., Keck, L., Jiang, J., Scheckman, J., McMurry, P. H., Deng, Z., Zhao, C. S., Moerman, M., Henzing, B., and de Leeuw, G.: Particle mobility size spectrometers: harmonization of technical standards and data structure to facilitate high quality long-term observations of atmospheric particle number size distributions, Atmos. Meas. Tech. Discuss., 3, 5521-5587, doi:10.5194/amtd-3-5521- 
2010, 2010.

Yum, S. S. and Hudson, J. G.: Wintertime/summertime contrasts of cloud condensation nuclei and cloud microphysics over the Southern Ocean, J. Geophys. Res., 109, D06204, doi:10.1029/2003JD003864, 2004.

Yum, S. S., Hudson, J. G., Song, K. Y., and Choi, B.C.: Springtime cloud condensation nuclei concentrations on the west coast of Korea, Geophys. Res. Lett., 32, L09814, doi:10.1029/2005GL022641, 2005.
Zhang, Q., Ma, X. C., Tie, X., Huang, M., and Zhao, C.: Vertical distributions of aerosols under different weather conditions: Analysis of in-situ aircraft measurements in Beijing, China, Atmos. Environ., 43, 5526-5535, doi:10.1016/j.atmosenv.2009.05.037, 2009. 